(10.1) University of Glasgow

Adam Smith

Business School

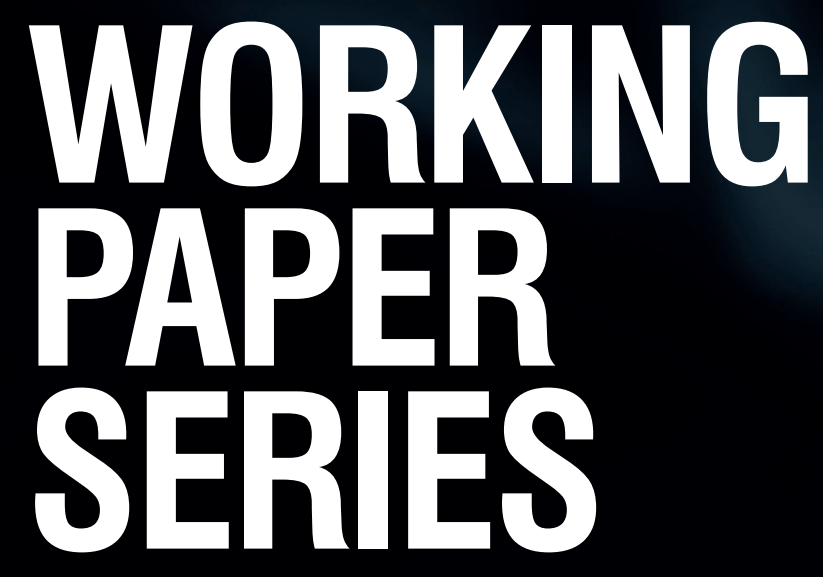

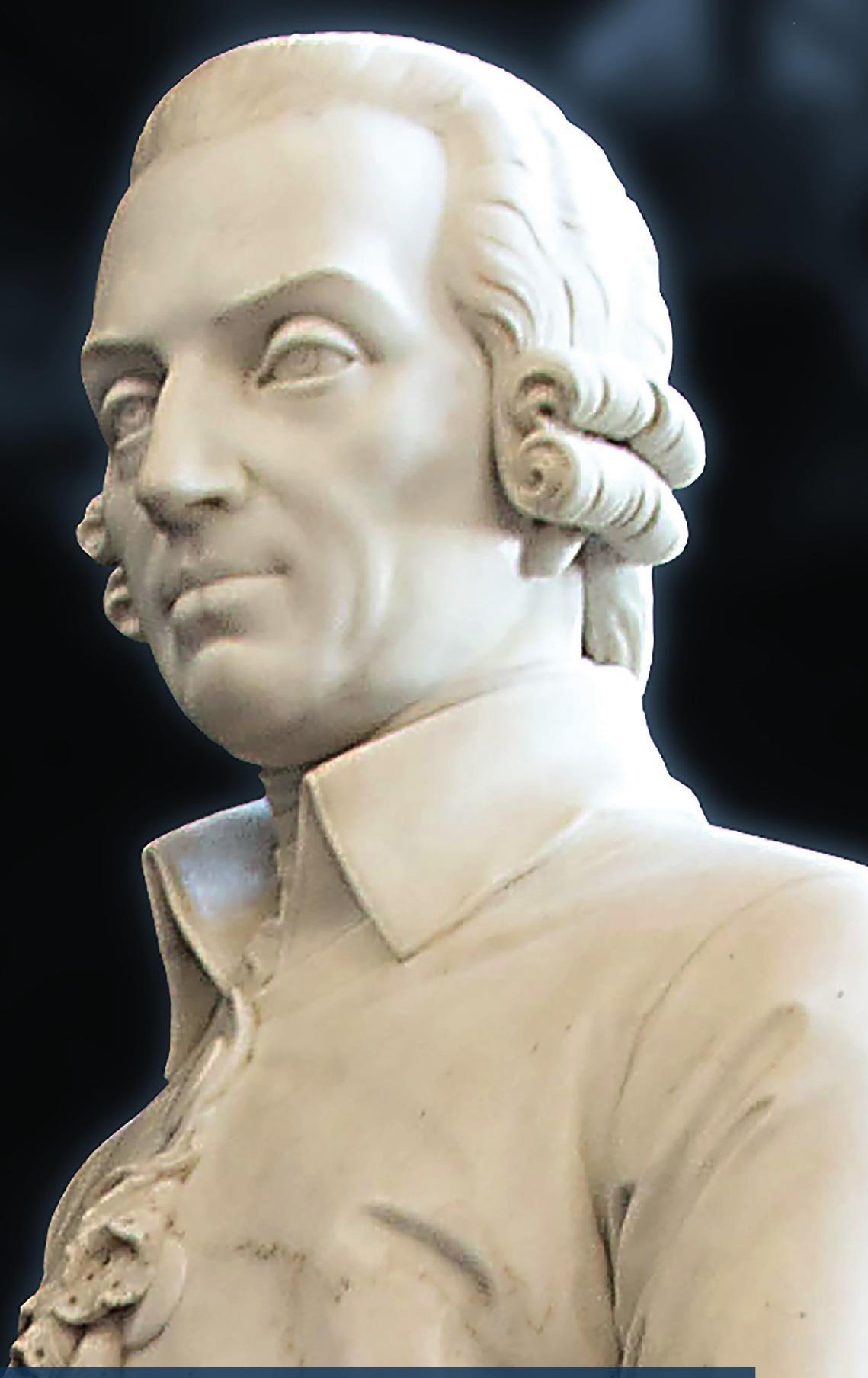

Original sin in corporate finance: New evidence from Asian bond issuers in onshore and offshore markets

Paul Mizen, Frank Packer, Eli Remolona and Serafeim Tsoukas Paper no. 2021-03 March 2021 


\title{
Original sin in corporate finance: New evidence from Asian bond issuers in onshore and offshore markets*
}

\author{
Paul Mizen ${ }^{\mathrm{a}}$, Frank Packer ${ }^{\mathrm{b}}$, Eli Remolona ${ }^{\mathrm{c}}$ and Serafeim Tsoukas ${ }^{\mathrm{d}}$ \\ ${ }^{a}$ University of Nottingham, UK \\ ${ }^{\mathrm{b}}$ Bank for International Settlements \\ ${ }^{\mathrm{d}}$ University of Glasgow, UK \\ ${ }^{\mathrm{c}}$ Asia School of Business
}

March 17, 2021

\begin{abstract}
In this paper, we focus on the surprising phenomenon in which firms face difficulty issuing in domestic currency even in the home market, especially in emerging markets. Could this be due to "original sin" which has been familiar to sovereign bond issuance? In its new incarnation, original sin refers to the difficulty firms in many emerging markets have in borrowing domestically long-term, even in the local currency. We infer the nature of original sin from 5,901 financing decisions by firms in seven Asian emerging markets over a period of 20 years. Our sample period covers an episode when bond issuers had a choice between a less developed but growing onshore market, which varied across countries in the level of development, and a deep and liquid offshore market. We find that even in countries with onshore markets, it is often easier for unseasoned firms to issue offshore (in foreign currency) than to issue onshore, but changes in market development reverses this effect. In addition, once such a firm becomes a seasoned issuer, it is absolved from domestic original sin and is then able to act opportunistically and go to the market favored by interest differentials.

Key words: bond financing, offshore markets, emerging markets, market depth, global credit

JEL: C23, E44, F32, F34, G32, O16

${ }^{*}$ Corresponding Author: Paul Mizen, Professor of Monetary Economics, University of Nottingham, University Park, Nottingham, NG7 2RD, England; Tel ++ 44115951 5479; Email: paul.mizen@nottingham.ac.uk. The first and fourth authors gratefully acknowledge the support of the Bank for International Settlements and their generous hospitality during the period that this paper was prepared. Tsoukas is also grateful to Carnegie Trust for financial support. We are grateful to Menzie Chinn (editor) and one anonymous reviewer for insightful comments and suggestions. We thank Joe Byrne, Michael Funke, Maurizio Habib, Jean Helwege, Hienz Herrmann, Matthias Hoffmann, Iikka Korhonen, Nelson Mark, Mark Spiegel, Philip Turner, and participants at the Bundesbank 3rd Workshop on "Money, Finance, and Banking in East Asia", the Bank Negara Malaysia Economics Research Workshop, the Bank of Korea, the Annual European Meeting of the Econometric Society, the Annual Asian Meeting of the Econometric Society, and seminar participants at the University of Glasgow and the University of Birmingham for comments and suggestions. We also thank Marjorie Santos and Jimmy Shek for excellent research assistance. The views expressed in this paper are those of their authors and not necessarily the views of the BIS. Any remaining errors are our own.
\end{abstract}




\section{Introduction}

Not long after Eichengreen and Hausman (1999) first proposed the concept of original sin as the inability of a government to issue offshore in its own currency, speculation arose in Hausmann and Panizza (2003) whether original sin occurs due to badly designed domestic policies and institutions or the organization of capital markets. Hausmann and Panizza (2003) found much more compelling reasons to think determinants of a country's capacity to borrow at home at long duration and in local currency were related to features of the local bond markets e.g. capital controls than domestic policies and institutions. A wide range of papers examined this question for sovereign borrowers, and steps have been taken, summarized in Hausmann and Panizza (2011), to deal with the root causes. It has been asked whether corporate borrowers faced the same problem when issuing in domestic currency. Allayannis, Brown and Klapper (2003) suggest that many firms in emerging markets are not able to issue bonds onshore, at least not large quantities nor at long maturities, and we identify a puzzle why firms in emerging markets often issue debt abroad while shunning their own local bond markets. Possibly, for certain kinds of firms in emerging economies, original sin is the inability to issue onshore instead of offshore. Yet Burger, Warnock and Warnock (2012), Burger, Sengupta, Warnock and Warnock (2015) and Du and Schreger (2016) have recorded the increase in investment in emerging market corporate debt. In this paper, therefore, we focus on why emerging market firms face difficulty issuing in domestic currency even in the home market.

We begin by asking whether firms suffer a kind of "original sin" that makes it difficult to issue at home for reasons connected with the depth, liquidity, cost and efficiency of financial markets in emerging economies. ${ }^{1}$ Our paper contributes to the literature by examining the issuance behavior of firms in emerging Asia since 2000 to see what determines their decision to issue a bond in the first place, and how they choose between onshore and offshore

\footnotetext{
${ }^{1}$ Hale et al. (2020) cite poor macroeconomic fundamentals as a factor behind issuance onshore but their focus is on a mixture of advanced and emerging economies.
} 
markets. Our paper focuses exclusively on emerging corporate issuance, where the recent rapid growth that has occurred. Following Hausmann and Panizza's early results, we focus on the effect that financial market characteristics rather than macroeconomic conditions have had on corporate bond issuance in emerging markets to explain why firms in emerging markets often issue debt abroad and not at home. ${ }^{2}$ To explore these matters we ask two pertinent questions: How did changes in the development of offshore and onshore markets affect whether and where firms issue bonds? Can we identify firm characteristics that predict which firms will issue offshore and thus avoid original sin? In our case, much like Hausmann and Panizza (2003), we find that improvements in local bond market depth, tax treatment, and emergence of derivatives markets wash away original sin.

The behavior of firms in emerging Asia in the aftermath of the 1997 crisis offers us a natural experiment. In varying degrees, many of these firms had access to two corporate bond markets: a hard-currency offshore market and a local-currency onshore market. Although the offshore market was deep and liquid from the outset, the onshore markets were initially small and illiquid (Burger and Warnock, 2006, 2007; Burger et al., 2012). Over time, the onshore markets grew rapidly even as they continued to vary across countries in their levels of development. Abraham, Cortina, and Schmukler (2021) find supporting evidence of the development of the domestic markets in Asia. They show that while international bond markets played an important role to the corporate financing boom in East Asia during the 1990s, domestic markets proved to be even more important since the global financial crisis.

We analyze over 5,900 bond financing decisions of firms in seven emerging Asian economies: Hong Kong SAR, Indonesia, Korea, Malaysia, the Philippines, Singapore, and Thailand over 2000-2019. We match yearly bond issuance data to issuing firm data and to market-level and country-level data. Then we analyze financing decisions by considering three sets of factors. First, we consider the country-specific features of the markets, namely the depth of the onshore market, the liquidity of the secondary market, the openness of the capital

\footnotetext{
${ }^{2}$ In our sample of seven Asian emerging markets, we find 474 cases of firms issuing offshore without having issued onshore.
} 
account, the availability of hedging instruments, and the economy-wide experience of firms issuing bonds abroad. Second, we consider cyclical market conditions, especially the relative interest costs between onshore and offshore markets. Finally, we consider firm-specific characteristics, including the variables that usually explain capital structure, as well as firm size and whether the firm is a seasoned issuer of corporate bonds. ${ }^{3}$

When it comes to the country-specific features of markets, we find that onshore market development indeed influences the choice of market. The deeper the onshore market becomes, the less likely it is that a given firm will issue offshore. This factor largely explains the rapid rise of onshore issuance in the decade following the 1997 Asian crisis, as documented in figure 1.

Nonetheless, other aspects of market development seem to work in the opposite direction. An open capital account makes it more likely that a firm will issue offshore, and so does the availability of hedging instruments. By 2010, market development in emerging Asia had reached the point where many firms could behave opportunistically in choosing the market for bond financing. Asian firms flocked to the offshore market, taking advantage of unusually low U.S. dollar interest rates, more open capital accounts, and hedging instruments (figure 1). As noted by Kim and Shin (2021), offshore bond issuance in emerging market economies has greater significance than onshore bond issuance as a transmission channel of global liquidity after 2010 .

Our results also shed light on the nature of original sin in a corporate context. Firms in emerging Asia seem to follow a sequence as they decide between onshore and offshore markets. We find that firms that issue offshore are more likely to be unseasoned, indicating that many novices in the bond market first cut their teeth in the offshore market. Original sin seems to be related to high fixed costs that first-time issuers face in a shallow and illiquid onshore market. For many firms, these fixed costs are apparently lower in the offshore market, which is deep and liquid. Once a firm manages to issue in the offshore market, this

\footnotetext{
${ }^{3} \mathrm{~A}$ seasoned issuer has prior exposure to local or international markets. We define this term more precisely in section 3.
} 
original sin is washed away. Nonetheless, even in corporate finance, domestic original sin does not seem to be absolute. Some firms are able to go to the onshore market for their very first bond issue, especially if the onshore market is relatively well developed. Once the firm becomes a seasoned issuer, it is able to respond more sensitively to the advantages conferred by tax treatment and depth of swap markets when choosing the market in which to issue.

In what follows, section 2 places our analysis in the context of the corporate finance literature. Section 3 describes the data and defines the variables used in the analysis. Section 4 characterizes the decision to issue a bond. Section 5 analyses the choice between onshore and offshore markets. Section 6 presents results for the types of firms that gain from market development. Section 7 checks the robustness of the main results. Finally, section 8 highlights the main conclusions.

\section{The context of the literature}

The literature on the overarching issue of original sin begins with Eichengreen and Hausman (1999), who use the term to refer to both the inability of many sovereigns to borrow abroad in domestic currency and borrow at long maturities domestically. However, despite touching on the issue of domestic market impediments in Eichengreen, Hausmann and Panizza (2005a), the authors later focus on the difficulty of issuing offshore in domestic currency (Eichengreen, Hausmann and Panizza, 2005b, 2007). ${ }^{4}$ In this paper we apply the concept of original sin to corporate bond issuance. It is our contention that in the case of corporate finance, a lack of development in domestic corporate bond markets is binding for many firms over the sample period, and thus a broader use of the term original sin as in the 1999 paper is appropriate.

This section examines the extent to which bond market characteristics over several dimensions affect the choice of markets in which to issue. The determinants of bond issuance, both offshore and onshore, can be largely motivated by the literature on corporate capi-

\footnotetext{
${ }^{4}$ Hale et al. (2020) also look at corporate finance, but like Eichengreen et al. (2005b, 2007) focus on the difficulty of offshore issuance in local currency. They argue that the global financial crisis encouraged greater home currency issuance offshore, particularly for firms in advanced economies with good fundamentals.
} 
tal structure and international bond issuance (Rajan and Zingales, 1995; Booth, Aivazian, Demirguc-Kunt and Maksimovic, 2001; Allayannis et al., 2003). This frames our analysis in terms of the influence of market depth and liquidity, issuance costs due to agency, transaction costs, and market interest rate conditions, as well as determinants related to capital market openness, including the ready availability of hedging instruments.

Market depth and liquidity matter when firms consider their preferred market for issuance. Typical measures include volume of outstanding securities and secondary market turnover, respectively. Asian firms are traditionally deterred by a lack of depth in onshore corporate bond markets, issuing in offshore markets instead when they sell large, long-maturity bond obligations (Allayannis et al., 2003; Chan, Chui, Packer and Remolona, 2011). Indeed, Habib and Joy (2010) and Siegfried, Simeonova and Vespro (2003) show that bond markets have greater issuance volumes when they are more liquid, offer lower bid-ask spreads, have higher turnover, and demonstrate lower entry costs.

At the same time, the development of government bond markets can be highly complementary to developing depth and liquidity in corporate bond markets. In particular, a liquid government bond market can provide a "benchmark effect" that facilitates the pricing of bonds for corporate borrowers. In order to achieve effective pricing, certain key parts of the yield curve should be populated by government bonds (Chan et al., 2011). ${ }^{5}$

At the firm level, we expect agency costs to affect costs of issuance and the capital structure decision. Extending Myers and Majluf (1984), we consider the possibility of a pecking order in the choice of onshore versus offshore markets: firms issue in highly liquid offshore markets if they can; otherwise they use smaller onshore markets. Offshore issuers may be the ones most capable of alleviating agency cost concerns. The use of collateral assets (Demirguc-Kunt and Maksimovic, 1999; Booth et al., 2001), greater information provision (often associated with greater firm size), and access to high-quality lenders and markets

\footnotetext{
${ }^{5}$ Siegfried et al. (2003) thus include measures of duration in government bond markets as an explanatory variable explaining corporate bond issuance, noting that the choice of currency for long duration bond issuance can depend on the existence of long government duration in the same currency.
} 
(Titman and Trueman, 1986), all of which are associated with lower agency costs, may increase offshore issuance relative to onshore issuance.

Firm size is a convenient proxy measure for agency- and thus for transaction costs of bond issuance. That small firms find it more difficult to access international markets is consistent with Gozzi, Levine, Peria and Schmukler (2012), who show that large firms are consistently more likely to issue abroad- and at lower yield spreads than in domestic markets. Not surprisingly then, a small number of large firms account for the bulk of international capital raisings (Gozzi, Levine and Schmukler, 2010). However, size can matter in domestic markets as well. Didier and Schmukler (2013), for example, show that although domestic bond markets are increasingly important in emerging Asia, large firms drive most of the action. Thus, small firms can be rationed out of domestic as well as onshore markets due to informational concerns, and it is an empirical question whether firm size affects the likelihood of offshore issuance as opposed to domestic issuance.

Issuance costs are also closely related to contemporaneous market factors. Because offshore issuance is nearly always in foreign currency (mostly U.S. dollars), the literature frequently examines the role of interest rate differentials between foreign and domestic currency in determining issuance, both hedged and unhedged. A wide body of empirical work points to financially sophisticated corporations taking advantage of market windows of opportunity in overseas currencies to issue and then swap the obligations back into the domestic currency, (Graham and Harvey, 2001; McBrady and Schill, 2007, 2013; McBrady, Mortal and Schill, 2010; Munro and Wooldridge, 2010; Kim and Stulz, 1988). McBrady et al. (2010) conclude from the evidence on corporate bond issuance that issuers tend "to be opportunistic with prevailing uncovered yields" but are less responsive to covered yields, except when they are large, investment-grade firms in developed markets. Differential tax treatment within jurisdictions can also affect the net cost, and thus choice, of issuance venue (Newberry, 1998; Newberry and Dhaliwal, 2001).

The extent to which domestic capital markets are open to foreign investment is a critical 
factor in the onshore-versus-offshore bond-issuance decision (Burger et al., 2012). Burger et al. (2015) document evidence of a "steady increase in U.S. investors' allocations toward emerging market local currency bonds," which the global finance crisis did not stem, although investors treat EME assets differently. Broner, Lorenzoni and Schmukler (2013) find that investor-side factors play an important role in explaining the reliance on short-term maturities in foreign currency bond issuance by emerging-market sovereigns. Unfavorable withholding taxes and restrictions on foreign investors can be a significant deterrent to foreign investment in local markets for foreign investors, and thus hinder the depth and liquidity of those markets (Chan et al., 2011). Where countries impede cross-border investment, they enhance the offshore market.

Well-developed hedging markets enhance capital market openness. Access to swaps and derivatives to hedge interest payments on foreign currency obligations (and investors to hedge

foreign currency returns) can strengthen issuance in both foreign currency and domestic currency bond markets. Gczy, Minton and Schrand (1997), for example, find that the likelihood of using derivatives instruments is positively related to the exposure to FX risk and to the use of foreign currency debt. Allayannis and Ofek (2001) find that large multinationals are indifferent between the use of foreign currency bonds and the use of instruments to create synthetic foreign currency positions. In Asia, Allayannis et al. (2003) find that the availability of currency derivatives also makes domestic and foreign currency debt closer substitutes. At the same time, from the investor side, managing FX risks is more effective if there is a well-developed derivatives market (Black and Munro, 2010).

\section{Data}

\subsection{Data sources and definitions}

Our data are drawn from bond issues in both onshore and offshore markets and from balance sheet and profit-and-loss information provided at the firm level for seven Asian economies. 
This separates our study from the majority of studies that rely on bond issuance data without issuer (firm-level) information. We use Bloomberg to identify all corporate bonds issued by firms in Hong Kong SAR, Indonesia, Korea, Malaysia, the Philippines, Singapore, and Thailand from 2000 to 2019. We collect accounting data from the Compustat Global database. The matching of the bonds with the accounting data was made feasible using ISIN codes. We also hand-match firms in Bloomberg to Compustat using company names following a process that is common in the literature to merge firm with transaction level data (e.g Mizen and Tsoukas, 2012; Almeida, Cunha, Ferreira and Restrepo, 2017; Acharya, Eisert, Eufinger and Hirsch, 2018).

We start with an initial sample of 73,532 firm-year observations. We then apply the following criteria, which are common in the literature. First, we exclude firm-years with missing values for our explanatory variables in the main models. This reduces the sample to 65,100 observations. Second, we control for the potential influence of outliers by excluding observations in the $1 \%$ tails of the distribution for each variable included in the regressions. As a result, our sample is reduced to 60,047 firm-year observations. Finally, we allow for the entry and exit of firms, as the use of an unbalanced panel partially mitigates potential selection and survivorship bias. ${ }^{6}$ Our sampled firms operate in different sectors, such as manufacturing, utilities, resources, services, and financial services. We observe East Asian corporate bonds as those issued by a firm located in East Asia either in an East Asian market or an international market. We define firms' nationality using the residence-based approach followed by the Bank of International Settlements (BIS) statistical analysis and other relevant literature (e.g Abraham et al., 2021). To classify debt issues as onshore or offshore, we use the main market in which the bonds are issued and compare it to the issuing firm's nationality (Gozzi et al., 2010, 2012). For issues that take place in more than one market, we treat them as separate offerings according to the market in which they are

\footnotetext{
${ }^{6}$ Note that the regressions reported in the tables of results contain a smaller number of observations due to the fact that we lag all firm-specific variables by one year to deal with endogeneity concerns and some market-specific variables have missing values over the sample period.
} 
issued.

Our sample period represents a significant development phase for emerging corporate bond markets, spurred by regional cooperation and lower issuance costs after the financial crisis. We gather information about the issue dates, denomination, currency, location, and maturity for the bonds measured. Our coverage of bond issues therefore embraces firms with issues in hard currencies, which are almost exclusively denominated in U.S. dollars, and firms with bonds denominated in local currency. ${ }^{7}$ Although local currency issuances first started to capture the market's attention in the late 1990s, new issues in local currency now exceed new issues in dollars for most countries. Therefore, it is important to consider both the local and international currency issues in the Asian markets. ${ }^{8}$

To focus on the role of market depth, we rely on updated statistics of the Bank for International Settlements (see Gruic and Wooldridge, 2012). The collection of market-level data is "year-end". The BIS data were revised in the early 2010s due to the growing disparity between the BIS international debt securities statistics and the data from other international organizations. The growing openness of local markets to foreign investors and issuers blurs the distinction between international and domestic debt securities. Historically, issues were deemed international if the securities were placed with international investors (including debt securities issued in the local market by local residents), but other compilers of securities statistics did not use this definition- and a disparity emerged between the two as international investors became buyers of debt issued locally and local issuers began to issue domestic-currency-denominated debt abroad. However, the revisions as described in Gruic and Wooldridge (2012) are incorporated in the recorded data over the sample period. The majority of the firm-level variables are standard- and are defined in the appendix, but we discuss market variables of particular significance below.

\footnotetext{
${ }^{7}$ The vast majority of the bonds issued offshore are denominated in U.S. dollars, with a small residual number in yen, and bonds issued onshore are mostly denominated in their local currency.

${ }^{8}$ Although multiple issues occur at the same time by the same issuer, our own discussions with corporate treasurers indicates that these differ with respect to bond maturity rather than bond seniority; therefore, tranching issues do not arise.
} 
The size of the onshore market, denoted by ONSHORE, is likely to matter, because it is an indicator of depth. At the same time, as firms in a given country issue offshore, some of the lessons of their experience are likely to be shared, in various ways, with other potential issuers in that country. This shared experience is an externality that is also likely to matter, and we measure it by the cumulative amount of offshore issuance, which we denote by $O F F E X P$. The above aggregate variables are constructed from both corporate (including financial) and sovereign bond issuance. ${ }^{9}$

We employ two indicators to measure firms' ability to substitute bond issuance with other sources. First, we calculate the size of the stock market using the stock market capitalization (STOCKCAP), defined as the logarithm of the capitalization of the domestic stock market. Second, we consider the quantity of funds that is channelled through the banking system to investors in the private sector (private bank credit/GDP). This indicator (BANKCR) captures the overall development in private banking system because it quantifies the extent to which new firms have opportunities to obtain bank finance (Baltagi, Demetriades and Law, 2009). Data on both indicators are taken from the World Development Indicators (WDI, January 2021 version).

It is generally accepted that investors are willing to invest in securities only if there is enough liquidity for them to sell and exit easily when needed, which depends on the trading volume exchanged in secondary markets. In the context of emerging markets, a large trading volume can help brokers to spread their fixed costs more widely and thus reduce transactions costs (Eichengreen and Luengnaruemitchai, 2006; Mizen and Tsoukas, 2014). Thus, we measure liquidity by using the trading volumes in the secondary markets $(T R V O L)$.

Relative borrowing costs offer an indicator of opportunistic reasons to issue in foreign

\footnotetext{
${ }^{9}$ In unreported regressions we obtain a breakdown of sovereign versus non-sovereign data for onshore and offshore issuance. We find that sovereign debt issuance has a role in deepening the market, such as building the benchmark yield curve. Moreover, this finding supports previous work which shows that the development of the corporate bond market was driven in part by development of the sovereign bond market (Mizen and Tsoukas, 2014). The results are available upon request.
} 
currency, following Kim and Stulz (1988), Graham and Harvey (2001), McBrady and Schill (2007), McBrady et al. (2010), Habib and Joy (2010) and Munro and Wooldridge (2010). ${ }^{10}$ We measure this using short-term (3-12 month) uncovered interest differentials $(S I D)$, although a long interest differential would give the same result.

Investor demand can be significantly influenced by tax treatment, so we define a dummy for withholding tax (WITHTAX) on foreign investors' holdings of local currency government bonds that is defined for each country and year, drawn from Chan et al. (2011) and KPMG (2019).

The availability of hedging opportunities is linked to the scale of the foreign exchange swaps, derivative and options market in each country. We use the sum of currency swaps, FX swaps, options, outright forwards and other derivatives (DERIV) based on the daily average turnover in April, by location of the counterparty, currency and reporting country from the BIS Triennial Survey. We interpolate the intervening years using a semi-annual survey conducted by the BIS.

The choice between markets will most likely depend on the openness of the capital account, which we measure using the Chinn-Ito index. This variable is based on the binary dummy variables that codify the tabulation of restrictions on cross-border financial transactions reported in the IMF's Annual Report on Exchange Arrangements and Exchange Restrictions (AREAER), recorded on a country-by-country basis. ${ }^{11}$

We make a distinction in our paper in the final section between financial firms and nonfinancial firms (which is determined by information on their sector) and by firms that are seasoned issuers and those that are unseasoned. A seasoned firm has issued a bond before, while an unseasoned firm has not. The former type of firm has paid fixed costs associated

\footnotetext{
${ }^{10}$ Other authors use a covered or uncovered long interest differential on annual average of yields on bonds of 5-10 year maturity in percentage points. We experimented with this variable, but found the short interest differential to be consistently more important. McBrady et al. (2010) show that for both covered and uncovered differentials the data show firms opt for currencies with lower yields when issuing bonds and this action tends to eliminate the differences over time.

${ }^{11}$ The Chinn-Ito is a de jure measure, so we also experiment with a de facto measure based on Lane and Milesi-Ferretti (2007) to measure openness. The results are very similar both quantitatively and qualitatively.
} 
with issuing in local or international currency for the first time and probably has established relationships with underwriters or important customers. The latter firms have no prior exposure to international or local markets. Given that our bond issuance data set begins in 2000, we use an initial sample period of three years to give firms a period of time to become a seasoned issuer (otherwise all firms would be unseasoned in our initial year).

\subsection{Descriptive statistics}

Our data allow us to analyze how issuing behavior changes over time for firms in our sample as the onshore markets in the different countries develop at different rates.

Table 1 shows there is some differentiation among onshore markets and offshore experience across countries. ${ }^{12}$ The smallest onshore markets are Indonesia, the Philippines and the city states of Hong Kong and Singapore. Malaysia and Thailand have larger onshore markets, and Korea has the largest. The experience of offshore issuance tends to be limited in Indonesia, the Philippines, Malaysia, and Thailand but more extensive in Singapore, Hong Kong, and Korea. Stock market capitalization is large in Korea and Hong Kong; it is medium-size elsewhere with the exception of the the Philippines. Stock market capitalization is much greater than onshore bond issuance in most cases, with the exception of Korea. As for the degree to which the banking system is developed, we observe that Hong Kong SAR tops the list, while the Philippines is noticeably less bank centered compared to other Asian economies. Last, trading volumes indicate that Hong Kong SAR' bond market is the most liquid with Singapore's market being in the bottom.

In table 2 we show the means and medians for the firm-specific explanatory variables for all firms (column 1), issuers versus nonissuers (columns 2-3), onshore versus offshore bond issuers (columns 5-6), seasoned issuers versus starters (columns 8-9), and financial versus non-financial firms (columns 11-12) separately. We also report p-values of tests of

\footnotetext{
${ }^{12}$ Later tests show that this segmentation does not lead to differentiation of underlying issuance behavior explained by a range of explanatory variables, but it does reflect the different magnitudes of the markets in each country and differences in growth rates.
} 
the equality of the means for each comparative group (null of equality). We observe that issuers tend to be larger than nonissuers and more leveraged. Issuers onshore are smallerbut also more highly collateralized and have higher investment needs than offshore issuers. Thus it seems onshore bond markets require less of issuers but require greater evidence of tangible assets than offshore markets. Seasoned firms tend to be larger, more leveraged, more profitable and require less investment compared to unseasoned firms, but in other respects they are very similar and do not reject equality-of-mean values. Financial firms are larger than nonfinancial firms, have lower ratios of investment to total assets, have greater leverage, are more collateralized and are generally less profitable. In all respects they have significantly different mean values compared to nonfinancial firms. These statistics justify further investigation of seasoned and nonseasoned firms and financial and nonfinancial firms separately.

The annual numbers of onshore and offshore issuers are in table 3 , as well as the percentage of each group that are unseasoned (that is, those that issued for the first time). Two stylized facts are apparent from the table. First, the percentage of unseasoned issuers is fairly steady for both onshore and offshore borrowers, ranging between $15 \%$ and $21 \%$ for onshore borrowers, and between $25 \%$ and $36 \%$ for offshore borrowers. There is no clear trend over time. Second, offshore borrowers are consistently more likely to be unseasoned, with a higher percentage of unseasoned issuers in every year.

Regression analysis will determine whether these bivariate relationships carry over to a multivariate framework, and that is where we now turn. Our empirical analysis proceeds in two steps. First, we examine what drives the decision to issue a bond. Second, we consider how firms choose between the onshore and offshore markets. 


\section{Corporate bond issuance}

\subsection{Methodology}

We estimate a Probit model to explain the determinants of bond issuance by firms in each country, defining the dependent variable, $B O N D_{i j t}$, as a dummy variable that equals one if firm $i$ issues a bond in domestic or foreign markets, in country $j$, in year $t$, and zero otherwise.

$$
\operatorname{Pr}\left(B O N D_{i j t}=1\right)=F\left(a_{0}+a_{1} Z_{j t}+a_{2} X_{i j t-1}+v_{t}+\epsilon_{i j t}\right)
$$

Our specification includes firm-specific regressors, $\mathbf{X}_{i j t}$, that indicate a firm's predisposition to issue in bond markets- and a firm's ability to overcome agency problems through the strength of its balance sheet evaluated for firm $i$, in country $j$, in year $t-1$. We lag all timevarying, firm-specific variables by one period to mitigate potential endogeneity concerns. Following Mizen and Tsoukas (2010) and Bose, MacDonald and Tsoukas (2019) we include controls for firm size, investment scaled by total assets, leverage, profitability, tangible assets (collateral). ${ }^{13}$ We allow for a firm being a previous issuer of a domestic or foreign bond to separate those firms that are previous issuers from new entrants to the market. ${ }^{14}$ Specifically, $P R E V D O M$ is a dummy variable that equals one if a firm had issued at any time in the domestic market in the past, and zero otherwise. PREVFOR is a dummy variable that equals one if a firm had issued at any time in the foreign market in the past, and zero otherwise. The $v_{t}$ denotes time fixed effects to control for macroeconomic shocks and $\epsilon_{i j t}$ is

\footnotetext{
${ }^{13}$ We also experiment with including country and industry dummies without obtaining radically different results.

${ }^{14}$ As a test of robustness we employ a bivariate probit model with sample selection often known as a Heckprobit model, which jointly-estimates both decisions of the firm (whether to issue and whether to issue in a foreign or domestic market) in a single model. This addresses the question of selectivity bias in our model. The two equations are the selection equation, which is a Probit regression to explain the decision to issue and the outcome equation, and a Probit regression to explain whether the firm issued in domestic or foreign market (observable only for those firms who actually issued a bond). In untabulated regressions, we find that the coefficient on the inverse Mills ratio in the outcome equation, which measures the selectivity bias associated with the endogeneity of bond issuance, is insignificant. In other words, selectivity bias is quantitatively unimportant, which validates separate estimation of these decisions in two steps.
} 
an error term. The standard errors are clustered at the firm level.

Vector $\mathbf{Z}_{j t}$ includes a choice of market variables for country $j$, in year $t$, guided by the existing empirical literature on the determinants of bond issuance. Determining whether market depth is important to the bond-issuance decision depends on whether we obtain positive coefficients associated with $O N S H O R E$ and $O F F E X P$ variables. Market liquidity is likely to be a critical factor and we incorporate $T R V O L$, which measures the USD value of local currency corporate bonds transacted in the secondary markets. We anticipate more liquid markets to increase the desirability of issuing bonds because of lowering the costs of entering and exiting the market for investors.

We also check whether the impact of the depth of the onshore market differs depending on the size of the firm by using the interaction term ONSHORE*SIZE. Larger firms may need a deeper market in which to make a large issue; therefore, market size matters even more for large firms that otherwise cannot issue in large enough amounts to make onshore participation worthwhile. We then consider whether there are any offsetting effects from the degree of capital-account openness by observing whether we find a positive coefficient associated with DERIV (size of the derivatives market) that makes the offshore market more attractive. In addition, we allow for cyclical factors by considering whether time-varying issuance and transaction costs matter if we obtain negative and significant coefficients associated with short interest differentials and withholding tax treatment $(S I D$ and $W I T H T A X) \cdot{ }^{15}$

Finally, we consider potential substitutes of the bond market by taking the stock market capitalization $(S T O C K C A P)$ and the ratio of private credit by deposit money banks to GDP $(B A N K C R)$. The former variable measures the size of the stock market and the latter the overall size of the banking sector. We expect a negative coefficient for the size of stock market and a positive coefficient for the banking indicator. The rationale is that stocks

\footnotetext{
${ }^{15}$ SID and WITHTAX are highly correlated with one another. Practically speaking, this means we cannot include both variables in one regression because of collinearity issues. However, in unreported regressions we find that our results are broadly unchanged to including both indicators in the same specification.
} 
act as substitutes, while banks offer substitutability opportunities. Our principal focus in this section is on market development indicators, $\mathbf{Z}_{j t}$, although we control for firm-specific regressors, $\mathbf{X}_{i j t}$, and return to evaluate the effects of firm characteristics later.

\subsection{Results}

In table 4 we measure how market development affects the probability of bond issuance. In column 1 we present a specification that includes firm-level characteristics and indicators of previous market experience. We find that the probability of bond issuance increases with previous market experience either onshore $(P R E V D O M)$ or offshore $(P R E V F O R)$, which implies that track record in the market is highly beneficial. In the remaining columns of table 4 we introduce various market development indicators.

We find that the scale measure for the domestic market, ONSHORE, has a small but

positive coefficient but is hardly ever significant. At the same time, the offshore market, OFFEXP, has a much stronger positive and more often significant effect. Scale of markets matters, supporting the market-depth hypothesis. As we shall see, when it comes to the choice between onshore and offshore markets, there will be opposing signs on these variables. However, when we ask what influences the decision to issue a bond, particularly offshore, it is scale that counts. This suggests that a small onshore market is likely to restrict the ability of firms to issue onshore.

We include stock market capitalization $(S T O C K C A P)$ and the degree to which financial intermediaries are developed $(B A N K C R)$. Both variables offer a test of the pecking-order theory and the static trade-off theory, because firms may prefer to raise funds in the stock market or from banks rather than in bond markets, especially if the other sources of finance are fairly large and active. We find that neither indicator influences firms' probability to issue a bond, but as we shall see in table 6, there is considerable heterogeneity in the response of seasoned and unseasoned firms which is masked in this table.

We then turn our attention to bond market liquidity, as measured by trading volume 
in the secondary market $(T R V O L)$. The estimation results show that, when the market is liquid firms are more likely to issue bonds. This finding concurs with our expectations and previous work because the more liquid the market is the lower its transactions costs and the less impact trades have on market price (see Mizen and Tsoukas, 2014).

When we consider the short interest differential, SID, between the onshore and offshore markets we find evidence of cyclical influences on issuance. Much of the literature explores the choice between alternative markets as a cost issue (see McBrady et al., 2010). Columns 2 and 4-5 of table 4- show SID has a coefficient with a negative sign, which suggests that opportunism in the timing of issuance depends on the relative cost of borrowing onshore versus offshore. This matches the findings in Graham and Harvey (2001), McBrady and Schill (2007, 2013), McBrady et al. (2010), Munro and Wooldridge (2010) and Kim and Stulz (1988). Firms are more likely to issue when the domestic nominal interest rate is low relative to the foreign rate. ${ }^{16}$

Two market-development indicators that influence the incentive to issue are the existence of withholding taxes (WITHTAX), which tests whether there are disincentives from withholding tax on investors, and the size of the foreign exchange swaps, derivative, and options markets $(D E R I V)$ in each country. In column 3 we find that WITHTAX has a negative and significant coefficient as expected. We interpret this as a negative influence of investor-unfriendly policies (as discussed by Burger et al., 2012) on the probability of issuance, because it indirectly diminishes the incentives for foreign investors to hold local currency bonds, and it provides evidence in favor of the static trade-off theory. DERIV, examined in column 5 of table 4 raises the probability of issue consistent with the static trade-off and risk-management theories because a larger volume of swaps, derivatives, and options turnover tends to provide a greater opportunity for firms as well as investors to hedge their exchange rate exposure (Allayannis et al., 2003; McBrady and Schill, 2007, 2013;

\footnotetext{
${ }^{16}$ The choice of a short maturity for the interest differential is not important, because we find in other (unreported) tests that a longer-maturity differential also has a negative sign. We do not include both variables in our regression, because they are highly collinear.
} 
McBrady et al., 2010). We find a positive and mildly significant coefficient in this model, supporting previous studies. The importance of attracting international investors is underlined by the tax treatment and derivatives market variables. Favorable conditions for investors spur issuance onshore and offshore, but they also increase exposure to the sentiment of asset managers and other investors.

Finally, we interact the size of the firm with the scale of the onshore market (ONSHORE*SIZE) in column 4. A positive and significant coefficient would show that larger firms are more likely to issue in a larger onshore market than smaller firms, which increases issuance in total. This further supports the market-depth hypothesis because a larger onshore market would promote migration from offshore to onshore markets as the latter increase in depth. However, the point estimate is positive but statistically insignificant suggesting that market depth is not the only consideration. We are aware that table 4 masks some differential effects on seasoned and unseasoned firms, but the focus in this table is on the question "what determines the decision to issue in the bond market?". When we come to table 6 this will shed more light on the heterogeneity between firms of different types.

\section{The choice between onshore and offshore markets}

\subsection{Methodology}

Once a firm has decided to issue, it is important to know how it chooses the market in which to issue and to what extent market development affects this choice. This lies at the heart of our question about original sin for corporate borrowers. Hence, we examine the factors that influence a firm's choice between onshore and offshore debt for those firms that did issue bonds. We focus on the probability of issuance in offshore markets for firms that are issuers. We generate FOREIGN $N_{i j t}$, which equals one if firm $i$, in country $j$, in year $t$, issues a bond 
offshore, and zero otherwise. ${ }^{17}$ We conduct a Probit analysis as before. Our model is:

$$
\operatorname{Pr}\left(F O R E I G N_{i j t}=1\right)=F\left(a_{0}+a_{1} Z_{j t}+a_{2} X_{i j t-1}+v_{t}+\epsilon_{i j t}\right)
$$

where $\mathbf{Z}_{j t}$ and $\mathbf{X}_{i j t-1}$ denote market- and firm-level variables, respectively. The remaining fixed effects remain unchanged. The hypothesis that market depth matters is supported if we observe (in table 5) opposite signs on coefficients for ONSHORE (expected to have a negative coefficient) and $O F F E X P$ (expected to have a positive coefficient). We continue to expect a negative and significant coefficient on STOCKCAP, which indicates the size of the equity market. A positive influence of $B A N K C R$ would indicate that as financial intermediaries develop, firms' prospects of offshore issuance improve. In addition, to the extent to which corporate bond market liquidity helps firms to issue offshore should be determined by a positive and significant coefficient on TRVOL. The hypothesis about capital account openness is supported if we find a positive coefficient for DERIV (as before), though we add three tests unmentioned in the literature. First, we expect the coefficient attached to $C H I N N-I T O$ to have a positive coefficient, indicating that greater capital market openness promotes foreign bond issuance. Second, we expect the effect to diminish as onshore markets grow, which a negative coefficient for the interaction term $C H I N N-$ $I T O * O N S H O R E$ will highlight. Greater onshore market depth and the impact of capital account liberalization should reduce the incentive to issue overseas. Furthermore, we expect larger firms to derive the advantages of capital account openness. Thus, we expect the coefficient on $C H I N N-I T O * S I Z E$ to be positive. Last, we expect cyclical influences to affect issuance if we observe negative and significant coefficients associated with short interest differentials and withholding tax treatment (SID and WITHTAX).

We also control for the maturity of the bonds, and following Tsuji (2005) and Mizen and Tsoukas (2012) we construct a dummy that equals one if the maturity of the bond is over 6

\footnotetext{
${ }^{17}$ We sum up all bond issues by firm $i$ in each year $t$, so all onshore bonds would be aggregated, and all offshore bonds would be aggregated, so we do not double count the issuance decision in each market.
} 
years, and equal to zero otherwise $(M A T D U M)$. Bonds with maturity of less than 6 years are generally considered to be short-term bonds, while those with maturity above 6 years are considered to be medium and long-term bonds. We anticipate firms with longer maturity to have a higher likelihood to issue in the offshore market (Black and Munro, 2010; Ba, Song and Zhou, 2017).

Our interest is in the sensitivity of the choice of market decision to measures of market development, the relative advantage of issuing in foreign markets based on the short-term interest differentials, withholding taxes, and financial openness using the Chinn-Ito index. This will determine how easily an investor can engage in cross border transactions.

\subsection{Results}

Table 5 reports the estimates of various models that examine the relationship between, market development measures, firm-specific characteristics and the probability that a firm will issue bonds offshore. ${ }^{18}$ The market indicators reveal that the absolute size of the market is a very significant factor in determining whether an issuer will go to the onshore or offshore market. We find that $O N S H O R E$ and $O F F E X P$ have a significant effect on the decision to issue offshore. Because we explore the issuance decision for firms that have already decided to issue, we expect a larger onshore market to reduce offshore issuance and a larger offshore exposure to increase it. This is indeed what we find. In table 5, the coefficient associated with ONSHORE is negative, but the coefficient associated with OFFEXP is positive; both are highly significant. The coefficient on ONSHORE is of greater absolute value than the coefficient on OFFEXP in all cases. This implies that, ceteris paribus, issuance offshore is diminished to a greater extent by onshore market development than it is increased by the offshore issuance experience of borrowers of the same jurisdiction. Both findings support our original sin hypothesis, as well as the pecking-order hypothesis, because firms issue offshore market bonds when the capacity of the local market is exhausted, making foreign

\footnotetext{
${ }^{18}$ The sample is smaller in table 5 than in table 4 because we now only consider issuers.
} 
bonds complements to local bonds. The firms revert to the domestic market as its capacity increases.

While the point estimates on the size of the stock market and liquidity of the secondary market are insignificant, we find that banking development is critically important. Across all specifications the coefficients on $B A N K C R$ are positive and significant at the one percent level. This finding suggests that firms' chances of issuing offshore are increasing in financial intermediary development, which is consistent with Hawkins (2002) who shows that bonds act as supplements to bank lending or the private sector in emerging economies. There are strong reasons to believe that increasing bank intermediation can lead to higher offshore issuance. A more diversified and efficient financial sector is likely to help firms to overcome costs of accessing the offshore market. Hence, the development of the banking system goes hand in hand with the growth of the offshore bond market (Eichengreen and Luengnaruemitchai, 2006).

The estimated influence of cyclical variables such as relative borrowing costs also supports the static trade-off and risk-management theories. The absolute size of the coefficients on $S I D$, as shown in columns 2 and 4-6 of table 5, reveals that the impact of the interest differential differs from Kim and Stulz (1988), McBrady and Schill (2007) and McBrady et al. (2010). SID is generally positive after 2009. The low absolute level of interest rates would make issuance cheaper, and a positive differential would create an incentive to issue offshore, but a positive $S I D$ during a period of unusually low U.S. interest rates would draw more investors to the onshore market in search of higher yields. As more detailed results in table 7 show, these conditions are more likely to persuade unseasoned firms to issue onshore.

The estimates on the withholding dummy (WITHTAX) also support the static trade-off and risk-management theories. The coefficient is significant at the $1 \%$ level. This suggests tax treatment is especially important to issuers in the offshore market, where the majority of international bonds are aimed at foreign investors.

The size of the swaps and derivatives markets $(D E R I V)$ has a positive and significant 
effect in column 6 of table 5 as expected, since the ability of firms to hedge their positions, supporting the risk-management theory, makes offshore issuance more attractive. This effect also has a high level of significance compared with the previous table, suggesting that the scale of the derivatives market is very important for the decision to issue in an offshore market. Issuers are reassured if they (and investors) can easily transform payments from one currency into another. We therefore conclude that the choice of market is determined by market depth, the incentives to issue, and the ability to hedge risk, which support the market depth, static trade-off and market-risk theories.

An important influence on issuance, with a large absolute coefficient value in table 5 , is financial openness of the countries in our sample. This finding in the corporate bond market mirrors Claessens, Klingebiel and Schmukler (2007), who find that capital market openness deepens the domestic and foreign government bond markets. Greater openness (a higher value of the Chinn-Ito index, $C H I N N-I T O)$ increases offshore bond issuance, perhaps because cross-border transactions are less restricted. When we interact the Chinn-Ito index with the logarithm of the size of the onshore market (CHINN-ITO*ONSHORE), there is a small negative effect on offshore bond issuance. This shows that as the onshore market gains depth, and the market becomes more open, issuers have a greater tendency to migrate to the onshore market. The explanation may be that firms return to the onshore market when they see depth and openness improving because they think investors are more confident about holding domestically issued bonds when the openness of the market increases. Interactions with size $(C H I N N-I T O * S I Z E)$ have a small positive effect, suggesting that larger firms participate to a greater extent offshore when markets are more open. This finding supports our hypothesis that larger firms are able to reap the benefits of capital account openness.

Finally, the point estimates for the firm controls support the notion that financial health matters for firms' decision to issue offshore. We also observe that firms that issue debt with longer maturity are more likely to access the offshore market. The latter finding is in line with earlier reported evidence (e.g Black and Munro, 2010; Ba et al., 2017). 


\section{Original sin: which firms gain the most from market development?}

\subsection{Methodology}

Here we explore whether different firms are more or less likely to decide to issue when bond markets are more developed. We do so by interacting indicators of firm types (seasoned versus unseasoned) with market-development variables, $Z_{j t}$. This question has not been addressed using micro data for emerging markets countries before. The estimated model for the bond issuance is:

$$
\operatorname{Pr}\left(B O N D_{i j t}=1\right)=F\left(a_{0}+a_{1} Z_{j t} * S E A S_{i j t}+a_{2} Z_{j t} *\left(1-S E A S_{i j t}\right)+a_{3} X_{i j t-1}+v_{t}+\epsilon_{i j t}\right)
$$

and the estimated model for the choice of market is:

$\operatorname{Pr}\left(F O R E I G N_{i j t}=1\right)=F\left(a_{0}+a_{1} Z_{j t} * S E A S_{i j t}+a_{2} Z_{j t} *\left(1-S E A S_{i j t}\right)+a_{3} X_{i j t-1}+v_{t}+\epsilon_{i j t}\right)$

where $S E A S_{i j t}$ is a dummy variable that equals one if a firm has issued at least once in the past, and zero otherwise. We expect unseasoned firms, which have not issued before and have not paid the fixed costs to enter the market, to be more sensitive to changes in market development. In other words, unseasoned firms should respond more to overall market development. If this hypothesis is true, when financial development takes place, which increases firm issuance, unseasoned firms should be more severely affected than their seasoned counterparts. The same logic applies to the choice of the market. Therefore, when considering the market indicators, we expect to find weaker effects on seasoned firms'

probabilities of issuance or choices of foreign market. That is, the coefficients for $Z_{j t} *(1-$ 
$\left.S E A S_{i j t}\right)$ should be larger than those for $Z_{j t}{ }^{*} S E A S_{i j t}$.

Finally, we explore the different responses to our explanatory variables according to whether a firm is a financial or nonfinancial firm, using definitions given in the data section. This sheds light on the types of firms that are more likely to gain from market development. Related to this, our results help us characterize the nature of original sin.

\subsection{Results}

We report results for the influence of market experience in table 6 . We separate nonfinancial firms (in columns 1-4) from financial firms (in columns 5-8). ${ }^{19}$ The results are quite striking.

First, the results show that onshore market depth affects seasoned and unseasoned firms in different ways. In columns 1-4 onshore market depth is mostly insignificant and quantitatively unimportant for nonfinancial firms. However, in columns 5-8, where we consider their financial counterparts, we find that onshore market positively influences issuance for unseasoned firms, but not for seasoned firms, where in fact a negative relationship is estimated. This can be justified because unseasoned issuers have no preexisting ties to any bond marketand stand to gain the most when market depth increases. However, it is surprising to see how clear this effect is in the data, especially for firms operating in the financial industry. We view this finding as evidence of the significant firm-level heterogeneity that is masked in table 4 where we pool together all types of firms. In a different study of the effects of the larger euro-area market after the launch of EMU, Hale and Spiegel (2012) find the euro area market affects unseasoned firms more than it affects seasoned firms. The reasoning follows our finding that onshore market development in Asia affects unseasoned firms to a greater extent.

The interaction of onshore market size with firm size reinforces the effects. Specifically, in columns 3 and 7 we consider the coefficients on the interaction term and we see that the positive effect of the larger onshore market is more potent for larger unseasoned firms in the

\footnotetext{
${ }^{19}$ We omit the coefficients on firm-specific variables from table 4 to save space as we use these variables as controls.
} 
financial sector. These findings strengthen the patterns we observed earlier. Interestingly, the advantages of onshore market depth are more pronounced for unseasoned issuers in the financial sector, for which the estimated coefficients are more consistently of the expected sign at high levels of significance than for other firms. This suggests that original sin is about the high fixed costs that first-time nonfinancial issuers tend to face in shallow and illiquid onshore markets. Initially, these costs seem lower in the offshore market, which has always been deep and liquid. The correlation between high fixed costs in the primary market and illiquidity in the secondary market suggests that both are related to problems with information and transparency about issuing firms.

Second, the results show that greater offshore market experience significantly increases the likelihood of bond issuance for unseasoned firms (financial and non-financial). Therefore, we conclude that although onshore market development benefits unseasoned issuers (especially financial unseasoned companies), offshore market experience is an externality that spans unseasoned firms irrespective of their sector of operation.

Third, the existence of an active stock market has a negative effect on issuance for unseasoned firms and this holds for both financial and nonfinancial firms. The significance of $S T O C K C A P$ implies that equity and bond markets have greater substitutability for unseasoned issuers than for other. In addition, the size of the banking sector, as captured by $B A N K C R$, attracts positive and significant coefficients for unseasoned firms, while the effect on the seasoned firms is insignificant. Hence, there is complementarity for unseasoned issuers. The latter findings lend support to Eichengreen and Luengnaruemitchai (2006), who argue that in Asian markets complementarities between banking systems and bond markets dominate.

Fourth, seasoned firms and financial firms tend to be more sensitive to cyclical variables such as interest differentials. These differentials tend to influence all issuers negatively, but the response to interest differentials is larger for unseasoned firms than for seasoned firms. Accordingly, when the differential falls, favoring bond issuance, seasoned firms respond more 
than unseasoned firms do. Because these firms have already incurred the fixed costs of issuing for the first time, they may need a smaller differential to justify issuing more bonds. By contrast, unseasoned nonfinancial firms respond more to interest differentials than seasoned firms do. Tax effects are significant, but only for unseasoned firms, and more for unseasoned financial firms. Thus, support for the static trade-off and risk-management theories varies by issuer type and indicates the importance of breaking down the data into financial versus nonfinancial and seasoned versus unseasoned firms.

Fifth, we observe that greater liquidity of the secondary market (TRVOL) has different effects on seasoned and unseasoned firms. It affects the likelihood of issuance for the latter group, significantly more for nonfinancial than financial firms. Finally, the size of the derivative market $(D E R I V)$ affects both types of firms but for nonfinancials only. The coefficient is larger for unseasoned firms and the p-value for the equality of the coefficients indicates a statistically significant difference between the two point estimates (see table A1).

As an additional exercise, we estimate in table 7 the earlier model on the choice of market, but, as in table 6, allowing for same interactions with (1-SEAS) and (SEAS) and splitting the sample into nonfinancial and financial firms. The variable we seek to explain is the probability of issuing a bond in an offshore market.

The absolute size of the onshore markets (ONSHORE) generally has a negative effect on offshore issuance for financial and nonfinancial firms, as well as for seasoned and unseasoned firms. This suggests that as the onshore market grows, it becomes a substitute for the offshore market. The effects are statistically significant for seasoned nonfinancial firms and unseasoned nonfinancial firms. Tests of equality of the coefficients suggest that the point estimates for unseasoned firms are significantly higher compared to their seasoned counterparts. Once again, the results are consistent with Hale and Spiegel (2012), who find that the emergence of a large onshore market due to the launch of EMU spurs onshore issuance by financial and nonfinancial firms at the expense of offshore issuance.

Offshore market experience has a strong effect on issuance in the offshore market for both 
seasoned and unseasoned firms. However, the results suggest that firms respond differently to the offshore market development: increases in offshore market depth have a greater impact on the probability of issuing offshore for unseasoned firms, particularly in the nonfinancial sector. This underlines one of the stylized facts mentioned earlier: offshore markets available to EM issuers are longstanding and large, but onshore markets are relatively new- and have only recently acquired sufficient depth and liquidity to attract corporate issuers.

Next, we consider the alternatives to offshore bond financing, namely STOCKCAP and $B A N K C R$. The former variable attracts negative and significant coefficients for unseasoned firms both for nonfinancial and financial firms. Hence, unseasoned firms respond more strongly to developments of the stock market. The latter market variable shows that as banks' size increases so is the probability of issuing offshore. To sum up, we confirm that stock markets offer alternative options for external financing, while banks are complements to offshore bond financing.

Greater openness of the capital account has a positive effect on offshore issuance for all types of companies, both seasoned and unseasoned. When we interact this variable with the size of the onshore market, we find that it reinforces the negative effect of a larger onshore market. That is when the country has a high Chinn-Ito index and its onshore market is large, nonfinancial firms reduce their offshore issues. This effect is larger for unseasoned nonfinancial issuers than for seasoned nonfinancial issuers, but it is mainly insignificant for financial issuers. When we interact the Chinn-Ito index with firm size, we find that larger nonfinancial firms tend to issue less in the offshore market when the Chinn-Ito index is higher.

Other variables show the expected signs- but have different levels of significance. Socalled opportunistic factors do matter. The interest differential (SID) has a negative influence on the propensity of financial firms to issue, and more for unseasoned than seasoned financial firms. This reinforces our finding in table 5 that these conditions are more likely to persuade unseasoned firms without the benefit of previous issuance history, to issue onshore. 
The withholding tax (WITHTAX) has the expected strong negative effect on unseasoned firms. In addition, for nonfinancial firms, TRVOL exhibits a negative and much larger coefficient for unseasoned firms. A test for the equality of the coefficients, which is reported in the appendix, reveals that the differences in the coefficients on trading volume for unseasoned firms in the nonfinancial sector are statistically significant. Last, the size of the swaps and derivatives markets ( $D E R I V)$ has a positive and significant effect on the likelihood of offshore issuance for both nonfinancial firms and seasoned nonfinancial firms, consistent with the desirability of offshore issuance growing as hedging markets get deeper. This supports the risk-management theory.

In summary, the results reinforce several messages from the previous section. Larger onshore markets attract issuance, especially from unseasoned issuers, but more experience offshore spurs greater issuance all around. However, significant differences exist in the sensitivity of seasoned and unseasoned issuers and financial and nonfinancial firms regarding market depth, interest differentials, stock and bank markets and transactions costs. Notably, greater market depth in onshore markets encourages less offshore issuance, especially if the firms are in the financial sector. Even more strikingly, capital market openness encourages unseasoned firms to issue onshore, and the more open the capital market, the more that market depth in onshore markets influences the choice of markets.

\section{Robustness tests}

We conduct a series of robustness tests for the results in the previous sections.

\subsection{Addressing endogeneity concerns}

We report the results for the Linear IV Probit model to ensure that correlation between variables and the error terms does not influence our results. This sensitivity test is aimed at dealing with potential endogenous variables in our regression models as the firm-specific 
characteristics. Instruments include all firm-specific variables lagged twice or more. ${ }^{20}$ We start by examining the choice of issuance in table 8 . As it shows, we continue to observe the positive influence of $O F F E X P$ on the probability of issuance, while $O N S H O R E$ is no longer significant. We also confirm that other market-specific indicators such as the SID, TRVOL, DERIV and WITHTAX remain quantitatively and qualitatively similar. When we examine the choice of market using a linear IV Probit estimate in table 9, we find that the variables show similar signs and levels of significance. The only exception is the $D E R I V$ variable which is statistically insignificant.

At the foot of both tables we report p-values for the Sargan test and Kleibergen-Paap rk LM test, and we establish instrument validity. The Sargan test is a test for overidentifying restrictions implying that the excluded instruments are distributed independently of the error process (i.e. a joint null hypothesis that the instruments are uncorrelated with the error term and that the excluded instruments are correctly excluded from the estimated equation). ${ }^{21}$ The Kleibergen-Paap test is an underidentification test to show the instruments are adequate to identify the equation. ${ }^{22}$ We strongly reject the null in both cases, so our model is neither invalid nor underidentified as far as the instruments are concerned. Having dealt with potential endogeneity of variables in this way, we conclude that the results in tables 4 and 5 are maintained. ${ }^{23}$

\subsection{Alternative sample}

Thus far we conduct our analysis including Hong Kong and Singapore in our sample. However, these two major international centers of finance and trade, may not be very comparable

\footnotetext{
${ }^{20}$ We also considered instrumenting the market variables with lagged values without altering our results.

${ }^{21}$ Under the null hypothesis, the test has a chi-squared distribution with degrees of freedom equal to the number of overidentifying restrictions. P-values less than 0.05 show the null can be rejected at the $5 \%$ level. Hence, our instruments are valid.

${ }^{22}$ Again a p-value smaller than 0.05 suggests that the model is identified, meaning that the relationship between the included endogenous regressors and the instruments is sufficiently strong to justify inference from the results. A p-value larger than 0.05 indicates that the model is underidentified or too weakly identified to justify inference from the model.

${ }^{23}$ We also examine the F-statistics from the first-stage estimates for the IV models and obtain p-values close to zero, implying that our models do not suffer from a weak instrument problem.
} 
to the other countries in the sample, particularly because they are also relatively small in terms of GDP relative to trade and financial activity. To address this potential concern, we rerun our baseline models without Hong Kong and Singapore.

We report the results of this exercise in tables 10 and 11 . In the former table we find that the vast majority of the market variables retain their signs and significance confirming that firms improve their chances of issuance when market indicators improve. When we examine the choice of market in table 11, we further corroborate that market development is more potent for firms deciding to issue offshore. We note, however, that offshore market and the Chinn-Ito index are no longer statistically significant. Overall, we conclude that our main results are broadly robust to an alternative sample that does not include Hong Kong SAR and Singapore, but some hypotheses do not remain intact.

\subsection{Double clustering}

In our specifications thus far we cluster standard errors at the firm level. To check the robustness of our results in this section, we also allow for repeated observations of macroeconomic variables within each country for a given firm by clustering standard errors at the firm level and the country-year level. The results in tables 12 and 13 replicate tables 4 and 5 with double clustering. The results are essentially the same and in terms of significance, table 13 shows little change. Table 14 reports lower significance on OFFEXP and insignificance on $S T O C K C A P$ as explanatory variables for the choice of market, but OFFEXP is still significant. Other variables are significant as before. Our conclusions do not change through double clustering.

\section{Conclusions}

Why do firms in emerging markets so often issue bonds abroad? We ask whether it reflects a kind of "original sin", specific to certain corporate borrowers that face an inability to 
issue onshore, at least not in size and not at long maturities. There is ample evidence of the prevalence of original sin in sovereign bond markets, where it affects the ability to issue abroad in local currency and at longer maturities. However, very little analysis of the corporate bond market exists. We make use of a natural experiment in Asia, where at least since the mid-1990s there have been two corporate bond markets: a hard-currency offshore market, and a local-currency onshore market. We show that as the onshore market grows-and we know the authorities took various measures to accelerate the development of the onshore market-total issuance expands, prompting firms to move onshore as original sin is removed. This suggests that changes in market development and original sin are closely related.

We also demonstrate that many firms in emerging Asia seem to follow a sequence as they decide between onshore and offshore markets. We find that firms that issue offshore are more likely to be unseasoned, indicating that they cut their teeth first in the offshore market before migrating to the onshore market, where original sin is related to the depth and high fixed costs of first-time bond issuance.

But original sin does not seem to be absolute. Some firms go to the onshore market for their very first bond issue, especially if the onshore market is relatively well developed. And once a firm becomes a seasoned issuer, it is able to join the ranks of opportunistic issuers and respond more sensitively to the cost advantages conferred by interest differentials and other factors when choosing the market in which to issue. The observed decisions of bond issuers are also consistent with the market depth, agency, static trade-off, and risk-management theories of finance.

It is not necessarily the case that recent changes in bond markets imply more stable issuance patterns going forward. As issuers become seasoned and domestic markets become more developed, the choice between onshore and offshore markets is likely to depend more and more on which market offers lower taxes or deeper swap markets. 


\section{References}

Abraham, F., Cortina, J. and Schmukler, S.: 2021, The rise of domestic capital markets for corporate financing: Lessons from East Asia, Journal of Banking and Finance 122, 105987.

Acharya, F., Eisert, T., Eufinger, C. and Hirsch, C.: 2018, Real effects of the sovereign debt crisis in Europe: Evidence from syndicated loans, Review of Financial Studies 31, 2855-2896.

Allayannis, G., Brown, G. and Klapper, L.: 2003, Capital structure and financial risk: Evidence from foreign debt use in East Asia, Journal of Finance 58, 2667-2709.

Allayannis, G. and Ofek, E.: 2001, Exchange rate exposure, hedging and the use of foreign currency derivatives, Journal of International Money and Finance 20, 273-296.

Almeida, F., Cunha, I., Ferreira, M., and Restrepo, F.: 2017, The real effects of credit ratings: The sovereign ceiling channel, Journal of Finance 72, 249-290.

Ba, Q., Song, F. and Zhou, P.: 2017, Why do firms issue bonds in the offshore market? Evidence from China, Working Paper 19, Hong Kong Institute for Monetary Research.

Baltagi, B., Demetriades, P. and Law, S.: 2009, Financial development and openness: Evidence from panel data, Journal of Development Economics 89, 285-296.

Black, S. and Munro, A.: 2010, Why issue bonds offshore?, Working Paper 332, Bank for International Settlements.

Booth, L., Aivazian, V., Demirguc-Kunt, A. and Maksimovic, V.: 2001, Capital structures in developing countries, Journal of Finance 56, 87-130.

Bose, U., MacDonald, R. and Tsoukas, S.: 2019, Policy initiatives and firms' access to external finance: Evidence from a panel of emerging Asian economies, Journal of Corporate Finance 59, 162-184.

Broner, F., Lorenzoni, G. and Schmukler, S.: 2013, Why do emerging economies borrow short-term?, Journal of the European Economic Association 11, 67-100.

Burger, J., Sengupta, R., Warnock, F. and Warnock, V.: 2015, US investment in global bonds: As the Fed pushes, some EMEs pull, Economic Policy 30, 729-766.

Burger, J. and Warnock, F.: 2006, Local currency bond markets, Staff Papers 53, International Monetary Fund.

Burger, J. and Warnock, F.: 2007, Foreign participation in local currency bond markets, Review of Financial Economics 16, 291-304.

Burger, J., Warnock, F. and Warnock, V.: 2012, Emerging local currency bond markets, Financial Analysts Journal 68, 73-93. 
Chan, E., Chui, M., Packer, F. and Remolona, E.: 2011, Local currency bond markets and the Asian Bond Funds 2 initiative, Working Paper 63, Bank for International Settlements.

Chinn, M. and Ito, H.: 2006, What matters for financial development? Capital controls, institutions, and interactions, Journal of Development Economics 81, 163-192.

Claessens, S., Klingebiel, D. and Schmukler, S.: 2007, Government bonds in domestic and foreign currency: the role of institutional and macroeconomic factors, Review of International Economics 15, 370-413.

Demirguc-Kunt, A. and Maksimovic, V.: 1999, Institutions, financial markets and firm debt maturity, Journal of Financial Economics 54, 295-336.

Didier, T. and Schmukler, S.: 2013, The financing and growth of firms in China and India: Evidence from capital markets, Journal of International Money and Finance 39, 111-137.

Du, W., Schreger, J.: 2016. Sovereign risk, currency risk, and corporate balance sheets. Harvard University, mimeo.

Eichengreen, B., Borensztein, E. and Panizza, U.: 2006, A tale of two markets: Bond market development in East Asia and Latin America, Occasional paper, Hong Kong Institute for Monetary Research.

Eichengreen, B. and Hausmann, R.: 1999, Exchange rates and financial fragility, Kansas City, MO: Federal Reserve Bank of Kansas City 329-368, New challenges for monetary policy.

Eichengreen, B., Hausmann, R. and Panizza, U.: 2005a, The pain of original sin, in B. Eichengreen and R. Hausmann (eds), Other people's money: Debt denomination and financial instability in emerging-market economies, 13-47. Chicago: University of Chicago Press.

Eichengreen, B., Hausmann, R. and Panizza, U.: 2005b, The mystery of original sin, in B. Eichengreen and R. Hausmann (eds), Other people's money: Debt denomination and financial instability in emerging-market economies, 233-265, Chicago: University of Chicago Press.

Eichengreen, B., Hausmann, R. and Panizza, U.: 2007, Currency mismacthes, debt intoleramce, and original sin: Why they are not the same and why it matters., Capital Controls and Capital Flows in Emerging Economies: Policies, Practices and Consequences., Chigaco, University of Chicago Press.

Eichengreen, B. and Luengnaruemitchai, P.: 2006, Why doesn't Asia have bigger bond markets?, BIS Papers chapters, in: Bank for International Settlements (ed.), Asian bond markets: Issues and prospects, 30, 40-77.

Gczy, C., Minton, B. and Schrand, C.: 1997, Why firms use currency derivatives, Journal of Finance 52, 1323-1354. 
Gozzi, J., Levine, R., Peria, S. and Schmukler, S.: 2012, How firms use domestic and international corporate bond markets, Working Paper 17763, National Bureau of Economic Research.

Gozzi, J., Levine, R. and Schmukler, S.: 2010, Patterns of international capital raisings, Journal of International Economics 80, 45-57.

Graham, J. and Harvey, C.: 2001, The theory and practice of corporate finance: Evidence from the field, Journal of Financial Economics 61, 187-243.

Gruic, B. and Wooldridge, P.: 2012, Enhancements to the BIS debt securities statistics, Quarterly Review, Bank for International Settlements.

Habib, M. and Joy, M.: 2010, Foreign-currency bonds: Currency choice and the role of uncovered and covered interest parity, Applied Financial Economics 20, 601-626.

Hale, G., Jones, P and Spiegel, M.: 2020, Home currency issuance in international bond markets, Journal of International Economics 122, 103256.

Hale, G. and Spiegel, M.: 2012, Currency composition of international bonds: The EMU effect, Journal of International Economics 88, 134-149.

Hausmann, R. and Panizza, U.: 2003, On the determinants of original sin: An empirical investigation, Journal of International Money and Finance, 22, 957-990.

Hausmann, R. and Panizza, U.: 2011, Redemption or abstinence? Original sin, currency mismatches and counter cyclical policies in the new millennium, Journal of Globalization and Development, 2, 1-35.

Hawkins, J.: 2002, Bond markets and banks in emerging economies, BIS Paper No. 11, Bank for International Settlements.

Kim, Y. and Stulz, R.: 1988, The eurobond market and corporate financial policy: A test of the clientele hypothesis, Journal of Financial Economics 22, 189-205.

Kim, S. and Shin, HS.: 2021, Offshore EME bond issuance and the transmission channels of global liquidity, Journal of International Money and Finance 112, 102336.

KPMG: 2019, Withholding Tax Study, The Luxembourg Investment Funds - Withholding Tax Study.

Lane, P. and Milesi-Ferretti, G.-M.: 2007, The external wealth of nations mark II: Revised and extended estimates of foreign assets and liabilities, 1970-2004, Journal of International Economics 73, 223-250.

McBrady, M., Mortal, S. and Schill, M.: 2010, Do firms believe in interest rate parity?, Review of Finance 14, 695-726.

McBrady, M. and Schill, M.: 2007, Foreign currency-denominated borrowing in the absence of operating incentives, Journal of Financial Economics 86, 145-177. 
McBrady, M. and Schill, M.: 2013, Opportunistic foreign currency debt issuance, in G. Caprio (ed.), The Evidence and Impact of Finanical Globalization, Elsevier, North Holland.

Mizen, P. and Tsoukas, S.: 2010, What effect has bond market development in emerging Asia had on the issuance of corporate bonds?, Working Paper 18/2010, Hong Kong Institute for Monetary Research.

Mizen, P. and Tsoukas, S.: 2012, The response of the external finance premium in Asian corporate bond markets to financial characteristics, financial constraints and two financial crises, Journal of Banking and Finance 36, 3048-3059.

Mizen, P. and Tsoukas, S.: 2014, What promotes greater use of the corporate bond market? A study of the issuance behaviour of firms in Asia, Oxford Economic Papers 66, 227-253.

Munro, A. and Wooldridge, P.: 2010, Motivation for swap covered foreign currency borrowing, Working Paper 52, Bank for International Settlements.

Myers, S. and Majluf, N.: 1984, Corporate financing and investment decisions when firms have information that investors do not have, Journal of Financial Economics 13, 187-221.

Newberry, K.: 1998, Foreign tax credit limitations and capital structure decisions, Journal of Accounting Research Spring 24, 157-166.

Newberry, K. and Dhaliwal, D.: 2001, Cross-jurisdictional income shifting by U.S multinationals: Evidence from international bond offerings, Journal of Accounting Research Spring 39, 643-662.

Rajan, R. and Zingales, L.: 1995, What do we know about capital structure? Some evidence from international data, Journal of Finance 50, 1421-1460.

Siegfried, N., Simeonova, E. and Vespro, C.: 2003, Choice of currency in bond issuance and the international role of currencies, Working Paper 814, European Central Bank.

Titman, S. and Trueman, B.: 1986, Information quality and the valuation of new issues, Journal of Accounting and Economics 8, 159-172.

Tsuji, C.: 2005, The credit-spread puzzle. Journal of International Money and Finance 7, 1073-1089. 
Figure 1: Corporate bond issuance in Asia

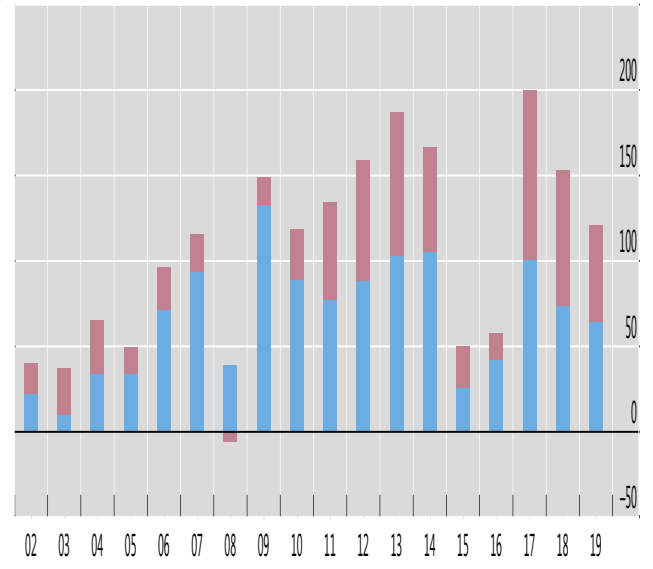

Onshore $\quad$ Olfshore

Notes: Net issues by both financial and nonfinancial issuers, aggregate of Chinese Taipei, Hong Kong SAR, Indonesia, Korea, the Philippines, Singapore, and Thailand. Onshore is proxied by BIS domestic debt securities, and offshore is proxied by BIS international debt securities. For Hong Kong SAR and Singapore, onshore is derived by subtracting BIS international debt securities from BIS total debt securities. Units are U.S. dollars deflated by U.S. CPI inflation, 2012 price. Sources: BIS; authors' calculations. 
Table 1: Summary Statistics by Country

\begin{tabular}{|c|c|c|c|c|c|c|c|}
\hline & $\begin{array}{c}\text { Hong Kong } \\
\text { (1) }\end{array}$ & $\begin{array}{c}\text { Indonesia } \\
(2)\end{array}$ & $\begin{array}{c}\text { Korea } \\
(3)\end{array}$ & $\begin{array}{c}\text { Malaysia } \\
\text { (4) }\end{array}$ & $\begin{array}{c}\text { Philippines } \\
\text { (5) }\end{array}$ & $\begin{array}{c}\text { Singapore } \\
\text { (6) }\end{array}$ & $\begin{array}{c}\text { Thailand } \\
\text { (7) }\end{array}$ \\
\hline ONSHORE & $\begin{array}{c}168.918 \\
(147.36)\end{array}$ & $\begin{array}{c}117.370 \\
(114.83)\end{array}$ & $\begin{array}{c}1231.111 \\
(1112.92)\end{array}$ & $\begin{array}{c}226.075 \\
(219.03)\end{array}$ & $\begin{array}{c}63.589 \\
(118.01)\end{array}$ & $\begin{array}{l}112.429 \\
(216.67)\end{array}$ & $\begin{array}{c}213.872 \\
(117.49)\end{array}$ \\
\hline OFFEXP & $\begin{array}{l}143.208 \\
(88.08)\end{array}$ & $\begin{array}{l}47.515 \\
(31.01)\end{array}$ & $\begin{array}{c}144.730 \\
(168.12)\end{array}$ & $\begin{array}{l}31.469 \\
(26.01)\end{array}$ & $\begin{array}{c}37.301 \\
(56.02)\end{array}$ & $\begin{array}{l}74.081 \\
(39.74)\end{array}$ & $\begin{array}{l}10.545 \\
(9.67)\end{array}$ \\
\hline STOCKCAP & $\begin{array}{c}2444.730 \\
(2411.60)\end{array}$ & $\begin{array}{l}248.019 \\
(211.11)\end{array}$ & $\begin{array}{c}1037.261 \\
(1079.11)\end{array}$ & $\begin{array}{l}327.603 \\
(300.08)\end{array}$ & $\begin{array}{l}154.997 \\
(150.07)\end{array}$ & $\begin{array}{l}474.239 \\
(481.80)\end{array}$ & $\begin{array}{r}473.729 \\
(418.19)\end{array}$ \\
\hline BANKCR & $\begin{array}{l}1.68 \\
(1.5)\end{array}$ & $\begin{array}{l}0.81 \\
(0.8)\end{array}$ & $\begin{array}{l}0.83 \\
(0.8)\end{array}$ & $\begin{array}{l}1.55 \\
(1.7)\end{array}$ & $\begin{array}{l}0.64 \\
(0.7)\end{array}$ & $\begin{array}{l}0.85 \\
(0.8)\end{array}$ & $\begin{array}{l}1.01 \\
(0.9)\end{array}$ \\
\hline TRVOL & $\begin{array}{c}32.20 \\
(31.80)\end{array}$ & $\begin{array}{c}12.77 \\
(13.88)\end{array}$ & $\begin{array}{c}10.037 \\
(4.8)\end{array}$ & $\begin{array}{c}4.66 \\
(3.12)\end{array}$ & $\begin{array}{c}1.85 \\
(1.20)\end{array}$ & $\begin{array}{c}1.32 \\
(1.69)\end{array}$ & $\begin{array}{c}4.22 \\
(5.52)\end{array}$ \\
\hline SID & $\begin{array}{l}-0.383 \\
(-0.27)\end{array}$ & $\begin{array}{l}6.811 \\
(6.65)\end{array}$ & $\begin{array}{l}6.748 \\
(1.29)\end{array}$ & $\begin{array}{l}1.130 \\
(1.04)\end{array}$ & $\begin{array}{l}2.111 \\
(1.55)\end{array}$ & $\begin{array}{l}-0.664 \\
(-0.17)\end{array}$ & $\begin{array}{l}-0.031 \\
(0.01)\end{array}$ \\
\hline DERIV & $\begin{array}{l}12.311 \\
(12.47)\end{array}$ & $\begin{array}{l}7.017 \\
(7.74)\end{array}$ & $\begin{array}{l}10.037 \\
(6.01)\end{array}$ & $\begin{array}{l}7.383 \\
(6.31)\end{array}$ & $\begin{array}{l}7.854 \\
(7.95)\end{array}$ & $\begin{array}{c}12.218 \\
(12.19)\end{array}$ & $\begin{array}{l}9.122 \\
(9.39)\end{array}$ \\
\hline SIZE & $\begin{array}{l}8.504 \\
(8.24)\end{array}$ & $\begin{array}{l}13.220 \\
(13.69)\end{array}$ & $\begin{array}{l}12.628 \\
(12.32)\end{array}$ & $\begin{array}{l}8.726 \\
(8.62)\end{array}$ & $\begin{array}{l}8.830 \\
(8.67)\end{array}$ & $\begin{array}{l}5.630 \\
(5.20)\end{array}$ & $\begin{array}{l}8.245 \\
(7.96)\end{array}$ \\
\hline INVA & $\begin{array}{l}0.331 \\
(0.24)\end{array}$ & $\begin{array}{l}0.529 \\
(0.49)\end{array}$ & $\begin{array}{l}0.500 \\
(0.48)\end{array}$ & $\begin{array}{l}0.473 \\
(0.37)\end{array}$ & $\begin{array}{l}0.482 \\
(0.41)\end{array}$ & $\begin{array}{l}0.456 \\
(0.39)\end{array}$ & $\begin{array}{l}0.618 \\
(0.59)\end{array}$ \\
\hline LEVER & $\begin{array}{l}0.101 \\
(0.05)\end{array}$ & $\begin{array}{l}0.135 \\
(0.07)\end{array}$ & $\begin{array}{c}0.08 \\
(0.04)\end{array}$ & $\begin{array}{l}0.114 \\
(0.05)\end{array}$ & $\begin{array}{l}0.117 \\
(0.05)\end{array}$ & $\begin{array}{l}0.098 \\
(0.04)\end{array}$ & $\begin{array}{l}0.109 \\
(0.04)\end{array}$ \\
\hline PROF & $\begin{array}{l}0.044 \\
(0.04)\end{array}$ & $\begin{array}{l}0.060 \\
(0.06)\end{array}$ & $\begin{array}{l}0.031 \\
(0.03)\end{array}$ & $\begin{array}{l}0.041 \\
(0.04)\end{array}$ & $\begin{array}{l}0.041 \\
0.04)\end{array}$ & $\begin{array}{l}0.043 \\
(0.04)\end{array}$ & $\begin{array}{l}0.058 \\
(0.05)\end{array}$ \\
\hline COLL & $\begin{array}{l}0.210 \\
(0.14)\end{array}$ & $\begin{array}{l}0.318 \\
(0.28)\end{array}$ & $\begin{array}{l}0.304 \\
(0.30)\end{array}$ & $\begin{array}{l}0.281 \\
(0.20)\end{array}$ & $\begin{array}{l}0.280 \\
(0.22)\end{array}$ & $\begin{array}{l}0.266 \\
(0.22)\end{array}$ & $\begin{array}{c}0.326 \\
(0.30)\end{array}$ \\
\hline
\end{tabular}

Notes: The table reports sample means with medians in parentheses. ONSHORE: Onshore debt securitization in USD bn. OFFEXP: Offshore debt securitization in USD bn. STOCKCAP: Stock market capitalization in USD bn. BANKCR: The ratio of private bank credit to GDP. TRVOL: The value of local currency corporate bonds transacted in the secondary markets in USD bn. SID: Short-interest differential between local and the U.S. nominal rates. DERIV: Turnover of the derivatives market. SIZE: Logarithm of total assets. INVA: Investments over total assets. LEVER: Long-term debt to total assets. PROF: Earnings before interest and taxes relative to total assets. COLL: Tangible assets relative to total assets. 
Table 2: Summary Statistics for the Firm-Specific Variables by Firm Type

\begin{tabular}{|c|c|c|c|c|c|c|c|c|c|c|c|c|c|}
\hline & $\begin{array}{l}\text { All Firms } \\
(1)\end{array}$ & $\begin{array}{c}\text { Issuers } \\
(2)\end{array}$ & $\begin{array}{c}\text { NonIssuers } \\
(3)\end{array}$ & $\begin{array}{l}\text { Diff. } \\
(4)\end{array}$ & $\begin{array}{c}\text { Onshore } \\
(5)\end{array}$ & $\begin{array}{c}\text { Offshore } \\
(6)\end{array}$ & $\begin{array}{c}\text { Diff. } \\
(7)\end{array}$ & $\begin{array}{c}\text { Seas } \\
(8)\end{array}$ & $\begin{array}{c}\text { Unseas } \\
(9)\end{array}$ & $\begin{array}{l}\text { Diff. } \\
(10)\end{array}$ & $\begin{array}{l}\text { Fin } \\
(11) \\
\end{array}$ & $\begin{array}{c}\text { NonFin } \\
(12)\end{array}$ & $\begin{array}{l}\text { Diff. } \\
(13)\end{array}$ \\
\hline$S I Z E$ & $\begin{array}{l}9.386 \\
(8.78)\end{array}$ & $\begin{array}{c}11.208 \\
(11.62)\end{array}$ & $\begin{array}{c}9.284 \\
(12.11)\end{array}$ & 0.00 & $\begin{array}{l}9.846 \\
(8.70)\end{array}$ & $\begin{array}{l}11.432 \\
(9.09)\end{array}$ & 0.00 & $\begin{array}{l}11.538 \\
(12.21)\end{array}$ & $\begin{array}{c}9.282 \\
(10.36)\end{array}$ & 0.00 & $\begin{array}{l}11.320 \\
(11.20)\end{array}$ & $\begin{array}{c}9.785 \\
(10.53)\end{array}$ & 0.00 \\
\hline$I N V A$ & $\begin{array}{l}0.488 \\
(0.46)\end{array}$ & $\begin{array}{l}0.480 \\
(0.43)\end{array}$ & $\begin{array}{l}0.504 \\
(0.45)\end{array}$ & 0.00 & $\begin{array}{l}0.533 \\
(0.49)\end{array}$ & $\begin{array}{l}0.489 \\
(0.44)\end{array}$ & 0.00 & $\begin{array}{l}0.488 \\
(0.47)\end{array}$ & $\begin{array}{l}0.523 \\
(0.48)\end{array}$ & 0.00 & $\begin{array}{c}0.050 \\
(0.01)\end{array}$ & $\begin{array}{l}0.568 \\
(0.52)\end{array}$ & 0.00 \\
\hline$L E V E R$ & $\begin{array}{l}0.102 \\
(0.05)\end{array}$ & $\begin{array}{l}0.133 \\
(0.09)\end{array}$ & $\begin{array}{l}0.084 \\
(0.04)\end{array}$ & 0.00 & $\begin{array}{l}0.129 \\
(0.09)\end{array}$ & $\begin{array}{l}0.110 \\
(0.05)\end{array}$ & 0.05 & $\begin{array}{l}0.121 \\
(0.07)\end{array}$ & $\begin{array}{l}0.093 \\
(0.04)\end{array}$ & 0.00 & $\begin{array}{l}0.121 \\
(0.06)\end{array}$ & $\begin{array}{l}0.092 \\
(0.04)\end{array}$ & 0.00 \\
\hline$P R O F$ & $\begin{array}{l}0.051 \\
(0.05)\end{array}$ & $\begin{array}{l}0.034 \\
(0.03)\end{array}$ & $\begin{array}{l}0.041 \\
(0.04)\end{array}$ & 0.00 & $\begin{array}{l}0.043 \\
(0.03)\end{array}$ & $\begin{array}{l}0.044 \\
(0.04)\end{array}$ & 0.49 & $\begin{array}{l}0.048 \\
(0.04)\end{array}$ & $\begin{array}{l}0.044 \\
(0.04)\end{array}$ & 0.02 & $\begin{array}{c}0.041 \\
(0.03)\end{array}$ & $\begin{array}{l}0.044 \\
(0.04)\end{array}$ & 0.00 \\
\hline$C O L L$ & $\begin{array}{l}0.309 \\
(0.26)\end{array}$ & $\begin{array}{l}0.289 \\
(0.29)\end{array}$ & $\begin{array}{l}0.285 \\
(0.27)\end{array}$ & 0.11 & $\begin{array}{l}0.305 \\
(0.28)\end{array}$ & $\begin{array}{l}0.291 \\
(0.23)\end{array}$ & 0.00 & $\begin{array}{l}0.303 \\
(0.28)\end{array}$ & $\begin{array}{l}0.297 \\
(0.29)\end{array}$ & 0.16 & $\begin{array}{c}0.060 \\
(0.02)\end{array}$ & $\begin{array}{l}0.327 \\
(0.31)\end{array}$ & 0.00 \\
\hline Obs & 42,888 & 13,484 & 29,404 & & 8,463 & 5,021 & & 4,418 & 38,470 & & 3,630 & 39,258 & \\
\hline
\end{tabular}

Notes: The table reports sample means with medians in parentheses. The p-value of a test of the equality of means is in columns labelled Diff. SIZE: Logarithm of total assets. INVA: Investments over total assets. LEVER: Long-term debt to total assets. PROF: Earnings before interest and taxes relative to total assets. COLL: Tangible assets relative to total assets.

Table 3: Distribution of Issuers Onshore and Offshore

\begin{tabular}{ccccc}
\hline & $\begin{array}{c}\text { Firms Issuing Onshore (A) } \\
(1)\end{array}$ & $\begin{array}{c}\text { \% of (A) Unseasoned } \\
(2)\end{array}$ & $\begin{array}{c}\text { Firms Issuing Offshore (B) } \\
(3)\end{array}$ & $\begin{array}{c}\text { \% of (B) Unseasoned } \\
(4)\end{array}$ \\
\hline 2000 & 304 & $19.1 \%$ & 81 & $32.0 \%$ \\
2001 & 383 & $21.6 \%$ & 96 & $34.1 \%$ \\
2002 & 422 & $21.8 \%$ & 105 & $33.6 \%$ \\
2003 & 473 & $21.5 \%$ & 111 & $36.5 \%$ \\
2004 & 507 & $20.1 \%$ & 118 & $36.9 \%$ \\
2005 & 537 & $20.2 \%$ & 126 & $35.2 \%$ \\
2006 & 554 & $20.4 \%$ & 127 & $32.4 \%$ \\
2007 & 584 & $19.3 \%$ & 127 & $34.9 \%$ \\
2008 & 611 & $19.4 \%$ & 128 & $29.8 \%$ \\
2009 & 631 & $18.5 \%$ & 131 & $32.1 \%$ \\
2010 & 645 & $18.8 \%$ & 131 & $33.5 \%$ \\
2011 & 732 & $16.5 \%$ & 136 & $31.6 \%$ \\
2012 & 747 & $16.1 \%$ & 133 & $30.8 \%$ \\
2013 & 790 & $15.1 \%$ & 134 & $31.3 \%$ \\
2014 & 776 & $15.8 \%$ & 133 & $29.0 \%$ \\
2015 & 806 & $15.2 \%$ & 134 & $29.1 \%$ \\
2016 & 803 & $15.2 \%$ & 132 & $28.7 \%$ \\
2017 & 791 & $15.3 \%$ & 127 & $28.3 \%$ \\
2018 & 781 & $15.6 \%$ & 127 & $27.7 \%$ \\
2019 & 741 & $15.4 \%$ & 119 & $25.3 \%$ \\
\hline
\end{tabular}

Notes: The table reports the distribution of issuing firms onshore and offshore. 
Table 4: Bond Issuance Decision

\begin{tabular}{|c|c|c|c|c|c|}
\hline & $(1)$ & $(2)$ & (3) & $(4)$ & $(5)$ \\
\hline PREVDOM & $\begin{array}{c}2.512^{* * *} \\
(36.25)\end{array}$ & $\begin{array}{c}2.460^{* * *} \\
(35.64)\end{array}$ & $\begin{array}{c}2.458^{* * *} \\
(35.58)\end{array}$ & $\begin{array}{c}2.459^{* * *} \\
(35.59)\end{array}$ & $\begin{array}{c}2.464^{* * *} \\
(34.00)\end{array}$ \\
\hline PREVFOR & $\begin{array}{c}1.523^{* * *} \\
(9.22)\end{array}$ & $\begin{array}{c}1.507^{* * *} \\
(9.04)\end{array}$ & $\begin{array}{c}1.500^{* * *} \\
(8.99)\end{array}$ & $\begin{array}{c}1.507^{* * *} \\
(9.05)\end{array}$ & $\begin{array}{c}1.536^{* * *} \\
(8.74)\end{array}$ \\
\hline ONSHORE & & $\begin{array}{c}0.107^{*} \\
(1.89)\end{array}$ & $\begin{array}{l}0.034 \\
(0.79)\end{array}$ & $\begin{array}{c}0.140^{* *} \\
(2.17)\end{array}$ & $\begin{array}{c}0.081^{*} \\
(1.67)\end{array}$ \\
\hline OFFEXP & & $\begin{array}{c}0.189^{* * *} \\
(4.51)\end{array}$ & $\begin{array}{c}0.226^{* * *} \\
(4.98)\end{array}$ & $\begin{array}{c}0.183^{* * *} \\
(4.40)\end{array}$ & $\begin{array}{c}0.177^{* * *} \\
(4.12)\end{array}$ \\
\hline STOCKCAP & & $\begin{array}{l}0.018 \\
(0.33)\end{array}$ & $\begin{array}{l}-0.045 \\
(-0.90)\end{array}$ & $\begin{array}{l}0.027 \\
(0.47)\end{array}$ & $\begin{array}{l}0.014 \\
(0.26)\end{array}$ \\
\hline BANKCR & & $\begin{array}{l}-0.024 \\
(-0.26)\end{array}$ & $\begin{array}{l}-0.094 \\
(-1.02)\end{array}$ & $\begin{array}{l}-0.011 \\
(-0.12)\end{array}$ & $\begin{array}{l}-0.033 \\
(-0.55)\end{array}$ \\
\hline TRVOL & & $\begin{array}{c}0.099^{* * *} \\
(2.82)\end{array}$ & $\begin{array}{l}0.059^{*} \\
(1.89)\end{array}$ & $\begin{array}{c}0.107^{* * *} \\
(3.00)\end{array}$ & $\begin{array}{c}0.088^{* * *} \\
(2.73)\end{array}$ \\
\hline SID & & $\begin{array}{c}-0.026^{* * *} \\
(-2.62)\end{array}$ & & $\begin{array}{c}-0.024^{* *} \\
(-2.24)\end{array}$ & $\begin{array}{c}-0.024^{* *} \\
(-2.29)\end{array}$ \\
\hline WITHTAX & & & $\begin{array}{c}-0.276^{* * *} \\
(-3.33)\end{array}$ & & \\
\hline ONSHORE*SIZE & & & & $\begin{array}{l}0.058 \\
(0.92)\end{array}$ & \\
\hline DERIV & & & & & $\begin{array}{l}0.001^{*} \\
(1.71)\end{array}$ \\
\hline SIZE & $\begin{array}{c}0.074^{* * *} \\
(7.02)\end{array}$ & $\begin{array}{c}0.087^{* * *} \\
(5.76)\end{array}$ & $\begin{array}{c}0.095^{* * *} \\
(5.73)\end{array}$ & $\begin{array}{c}0.084^{* * *} \\
(5.27)\end{array}$ & $\begin{array}{c}0.088^{* * *} \\
(5.36)\end{array}$ \\
\hline INVA & $\begin{array}{c}-0.362^{* *} \\
(-2.28)\end{array}$ & $\begin{array}{l}-0.207 \\
(-1.31)\end{array}$ & $\begin{array}{l}-0.198 \\
(-1.24)\end{array}$ & $\begin{array}{l}-0.205 \\
(-1.29)\end{array}$ & $\begin{array}{l}-0.211 \\
(-1.27)\end{array}$ \\
\hline LEVER & $\begin{array}{c}1.183^{* * *} \\
(5.70)\end{array}$ & $\begin{array}{c}1.439^{* * *} \\
(6.72)\end{array}$ & $\begin{array}{c}1.409^{* * *} \\
(6.53)\end{array}$ & $\begin{array}{c}1.448^{* * *} \\
(6.71)\end{array}$ & $\begin{array}{c}1.562^{* * *} \\
(6.84)\end{array}$ \\
\hline PROF & $\begin{array}{l}0.275 \\
(1.07)\end{array}$ & $\begin{array}{l}0.079 \\
(0.31)\end{array}$ & $\begin{array}{l}0.081 \\
(0.32)\end{array}$ & $\begin{array}{l}0.075 \\
(0.29)\end{array}$ & $\begin{array}{l}0.043 \\
(0.16)\end{array}$ \\
\hline COLL & $\begin{array}{c}-1.118^{* * *} \\
(-3.86)\end{array}$ & $\begin{array}{c}-0.843^{* * *} \\
(-2.91)\end{array}$ & $\begin{array}{c}-0.895^{* * *} \\
(-3.08)\end{array}$ & $\begin{array}{c}-0.840 * * * \\
(-2.90)\end{array}$ & $\begin{array}{c}-0.804^{* * *} \\
(-2.58)\end{array}$ \\
\hline Observations & 42,888 & 42,840 & 42,840 & 42,840 & 39,219 \\
\hline Number of Firms & 4,673 & 4,672 & 4,672 & 4,672 & 4,506 \\
\hline Pseudo R-squared & 0.54 & 0.55 & 0.55 & 0.55 & 0.55 \\
\hline
\end{tabular}

Notes: The table reports the effects of the variables listed on the probability to issue bonds by a Probit model. The dependent variable is a dummy that equals one if the firm is a bond issuer, and zero otherwise. All models include time fixed effects. Robust z-statistics are in parentheses. Standard errors are clustered at the firm level. All firm-specific variables are lagged one period. *significant at $10 \%$;* significant at $5 \%$;** significant at $1 \%$. 
Table 5: Choice of Market

\begin{tabular}{|c|c|c|c|c|c|c|}
\hline & (1) & $(2)$ & $(3)$ & $(4)$ & $(5)$ & $(6)$ \\
\hline ONSHORE & & $\begin{array}{c}-0.463^{* * *} \\
(-6.10)\end{array}$ & $\begin{array}{c}-0.428^{* * *} \\
(-6.56)\end{array}$ & $\begin{array}{c}-0.277^{* * *} \\
(-3.75)\end{array}$ & $\begin{array}{c}-0.539 * * * \\
(-6.90)\end{array}$ & $\begin{array}{c}-0.465^{* * *} \\
(-6.31)\end{array}$ \\
\hline OFFEXP & & $\begin{array}{c}0.150^{* *} \\
(2.57)\end{array}$ & $\begin{array}{c}0.215^{* * *} \\
(3.47)\end{array}$ & $\begin{array}{c}0.116^{* *} \\
(2.17)\end{array}$ & $\begin{array}{c}0.197^{* * *} \\
(3.07)\end{array}$ & $\begin{array}{c}0.178^{* * *} \\
(2.72)\end{array}$ \\
\hline STOCKCAP & & $\begin{array}{l}0.091 \\
(0.93)\end{array}$ & $\begin{array}{l}0.029 \\
(0.30)\end{array}$ & $\begin{array}{l}0.040 \\
(0.40)\end{array}$ & $\begin{array}{c}0.131 \\
(1.31)\end{array}$ & $\begin{array}{l}0.102 \\
(1.22)\end{array}$ \\
\hline BANKCR & & $\begin{array}{c}0.720^{* * *} \\
(5.70)\end{array}$ & $\begin{array}{c}0.714^{* * *} \\
(4.49)\end{array}$ & $\begin{array}{c}0.590^{* * *} \\
(4.75)\end{array}$ & $\begin{array}{c}0.694^{* * *} \\
(5.44)\end{array}$ & $\begin{array}{c}0.684^{* * *} \\
(5.42)\end{array}$ \\
\hline TRVOL & & $\begin{array}{l}0.019 \\
(0.32)\end{array}$ & $\begin{array}{l}0.046 \\
(0.74)\end{array}$ & $\begin{array}{l}-0.067 \\
(-1.16)\end{array}$ & $\begin{array}{l}0.048 \\
(0.81)\end{array}$ & $\begin{array}{l}0.002 \\
(0.04)\end{array}$ \\
\hline SID & & $\begin{array}{c}-0.075^{* * *} \\
(-3.33)\end{array}$ & & $\begin{array}{c}-0.095^{* * *} \\
(-3.88)\end{array}$ & $\begin{array}{c}-0.075^{* * *} \\
(-3.37)\end{array}$ & $\begin{array}{c}-0.087^{* * * *} \\
(-3.72)\end{array}$ \\
\hline WITHTAX & & & $\begin{array}{c}-0.351^{* * *} \\
(-2.75)\end{array}$ & & & \\
\hline CHINN-ITO & $\begin{array}{c}0.217^{* * *} \\
(3.94)\end{array}$ & $\begin{array}{c}0.039 \\
(1.24)\end{array}$ & $\begin{array}{l}0.041 \\
(1.29)\end{array}$ & $\begin{array}{c}0.144^{* * *} \\
(3.20)\end{array}$ & $\begin{array}{l}0.231 \\
(1.40)\end{array}$ & $\begin{array}{l}0.068^{*} \\
(1.69)\end{array}$ \\
\hline CHINN-ITO*ONSHORE & & & & $\begin{array}{c}-0.001^{* * *} \\
(-3.62)\end{array}$ & & \\
\hline CHINN-ITO*SIZE & & & & & $\begin{array}{l}0.023^{*} \\
(1.66)\end{array}$ & \\
\hline DERIV & & & & & & $\begin{array}{c}0.031^{* * *} \\
(2.74)\end{array}$ \\
\hline MATDUM & & $\begin{array}{c}0.170^{* * *} \\
(2.94)\end{array}$ & $\begin{array}{c}0.167^{* * *} \\
(2.89)\end{array}$ & $\begin{array}{c}0.166^{* * *} \\
(2.86)\end{array}$ & $\begin{array}{c}0.178^{* * *} \\
(3.06)\end{array}$ & $\begin{array}{c}0.197^{* * *} \\
(3.29)\end{array}$ \\
\hline SIZE & $\begin{array}{c}0.031^{*} \\
(1.78)\end{array}$ & $\begin{array}{c}0.110^{* * *} \\
(4.49)\end{array}$ & $\begin{array}{c}0.115^{* * *} \\
(4.51)\end{array}$ & $\begin{array}{c}0.115^{* * *} \\
(4.60)\end{array}$ & $\begin{array}{c}0.086^{* * *} \\
(3.01)\end{array}$ & $\begin{array}{c}0.108^{* * *} \\
(4.25)\end{array}$ \\
\hline INVA & $\begin{array}{l}-0.235 \\
(-0.99)\end{array}$ & $\begin{array}{l}-0.219 \\
(-0.94)\end{array}$ & $\begin{array}{l}-0.198 \\
(-0.86)\end{array}$ & $\begin{array}{l}-0.219 \\
(-0.95)\end{array}$ & $\begin{array}{l}-0.235 \\
(-1.02)\end{array}$ & $\begin{array}{l}-0.268 \\
(-1.12)\end{array}$ \\
\hline LEVER & $\begin{array}{c}0.903^{* * *} \\
(2.73)\end{array}$ & $\begin{array}{l}-0.083 \\
(-0.24)\end{array}$ & $\begin{array}{l}-0.101 \\
(-0.29)\end{array}$ & $\begin{array}{l}-0.135 \\
(-0.39)\end{array}$ & $\begin{array}{l}-0.105 \\
(-0.31)\end{array}$ & $\begin{array}{l}-0.091 \\
(-0.26)\end{array}$ \\
\hline PROF & $\begin{array}{l}0.663 \\
(1.40)\end{array}$ & $\begin{array}{l}0.069 \\
(0.14)\end{array}$ & $\begin{array}{l}-0.012 \\
(-0.02)\end{array}$ & $\begin{array}{l}-0.005 \\
(-0.01)\end{array}$ & $\begin{array}{c}0.102 \\
(0.20)\end{array}$ & $\begin{array}{c}0.063 \\
(0.12)\end{array}$ \\
\hline COLL & $\begin{array}{l}-0.146 \\
(-0.37)\end{array}$ & $\begin{array}{l}0.356 \\
(0.90)\end{array}$ & $\begin{array}{l}0.328 \\
(0.84)\end{array}$ & $\begin{array}{l}0.384 \\
(0.98)\end{array}$ & $\begin{array}{l}0.359 \\
(0.91)\end{array}$ & $\begin{array}{c}0.422 \\
(1.04)\end{array}$ \\
\hline Observations & 11,881 & 11,868 & 11,868 & 11,868 & 11,868 & 11,036 \\
\hline Number of Firms & 1,095 & 1,095 & 1,095 & 1,095 & 1,095 & 1,076 \\
\hline Pseudo R-squared & 0.03 & 0.14 & 0.14 & 0.14 & 0.14 & 0.14 \\
\hline
\end{tabular}

Notes: The table reports the effects of the variables listed on the probability to issue in an offshore market by a Probit model. The dependent variable is a dummy that equals one if the firm issues in a foreign market, and zero otherwise. All models include time fixed effects. Robust z-statistics are in parentheses. Standard errors are clustered at the firm level. All firm-specific variables are lagged one period. *significant at $10 \%$; ** significant at $5 \%$; *** significant at $1 \%$. 
Table 6: A More Detailed Breakdown for Bond Issuance

\begin{tabular}{|c|c|c|c|c|c|c|c|c|}
\hline & $(1)$ & $(2)$ & $(3)$ & $(4)$ & $(5)$ & (6) & $(7)$ & $(8)$ \\
\hline & nonfin & nonfin & nonfin & nonfin & fin & fin & fin & fin \\
\hline ONSHORE*SEAS & $\begin{array}{l}-0.098 \\
(-1.57)\end{array}$ & $\begin{array}{l}-0.056 \\
(-1.12)\end{array}$ & $\begin{array}{c}-0.157^{* *} \\
(-2.18)\end{array}$ & $\begin{array}{l}-0.061 \\
(-1.03)\end{array}$ & $\begin{array}{c}-0.335^{* *} \\
(-2.00)\end{array}$ & $\begin{array}{c}-0.282^{* *} \\
(-2.00)\end{array}$ & $\begin{array}{l}-0.203 \\
(-1.35)\end{array}$ & $\begin{array}{c}-0.329^{*} \\
(-1.88)\end{array}$ \\
\hline ONSHORE*(1-SEAS) & $\begin{array}{l}-0.131 \\
(-1.03)\end{array}$ & $\begin{array}{l}-0.030 \\
(-0.28)\end{array}$ & $\begin{array}{l}-0.175 \\
(-1.15)\end{array}$ & $\begin{array}{c}0.131^{*} \\
(1.91)\end{array}$ & $\begin{array}{c}0.787^{* * *} \\
(2.94)\end{array}$ & $\begin{array}{c}0.857 * * * \\
(3.72)\end{array}$ & $\begin{array}{l}0.549 \\
(1.56)\end{array}$ & $\begin{array}{c}0.844^{* * *} \\
(3.08)\end{array}$ \\
\hline OFFEXP*SEAS & $\begin{array}{l}0.067 \\
(0.97)\end{array}$ & $\begin{array}{l}0.096 \\
(1.32)\end{array}$ & $\begin{array}{l}0.066 \\
(0.85)\end{array}$ & $\begin{array}{l}0.068 \\
(0.87)\end{array}$ & $\begin{array}{l}0.118 \\
(1.01)\end{array}$ & $\begin{array}{l}0.085 \\
(0.60)\end{array}$ & $\begin{array}{l}0.086 \\
(0.53)\end{array}$ & $\begin{array}{l}0.244 \\
(1.50)\end{array}$ \\
\hline OFFEXP*(1-SEAS) & $\begin{array}{c}0.193^{* * *} \\
(4.25)\end{array}$ & $\begin{array}{c}0.232^{* * *} \\
(4.57)\end{array}$ & $\begin{array}{c}0.185^{* * *} \\
(4.07)\end{array}$ & $\begin{array}{c}0.155^{* * *} \\
(3.28)\end{array}$ & $\begin{array}{l}0.121 \\
(1.05)\end{array}$ & $\begin{array}{c}0.283^{* *} \\
(2.15)\end{array}$ & $\begin{array}{c}0.156^{* *} \\
(1.90)\end{array}$ & $\begin{array}{l}0.084 \\
(0.66)\end{array}$ \\
\hline STOCKCAP*SEAS & $\begin{array}{l}0.035 \\
(0.51)\end{array}$ & $\begin{array}{l}-0.011 \\
(-0.17)\end{array}$ & $\begin{array}{l}0.046 \\
(0.63)\end{array}$ & $\begin{array}{l}0.010 \\
(0.16)\end{array}$ & $\begin{array}{l}-0.127 \\
(-0.95)\end{array}$ & $\begin{array}{c}-0.264^{* *} \\
(-2.20)\end{array}$ & $\begin{array}{l}-0.153 \\
(-1.15)\end{array}$ & $\begin{array}{l}-0.126 \\
(-0.97)\end{array}$ \\
\hline STOCKCAP*(1-SEAS) & $\begin{array}{c}-0.326^{* * *} \\
(-3.28)\end{array}$ & $\begin{array}{c}-0.351 * * * \\
(-4.11)\end{array}$ & $\begin{array}{c}-0.320 * * * \\
(-3.28)\end{array}$ & $\begin{array}{c}-0.682^{* * *} \\
(-11.88)\end{array}$ & $\begin{array}{c}-0.424^{* * *} \\
(-2.65)\end{array}$ & $\begin{array}{c}-0.470^{* * *} \\
(-4.08)\end{array}$ & $\begin{array}{c}-0.391^{* *} \\
(-2.16)\end{array}$ & $\begin{array}{c}-0.389 * * * \\
(-2.83)\end{array}$ \\
\hline BANKCR*SEAS & $\begin{array}{l}-0.161 \\
(-1.55)\end{array}$ & $\begin{array}{l}-0.205 \\
(-1.61)\end{array}$ & $\begin{array}{l}-0.122 \\
(-1.15)\end{array}$ & $\begin{array}{l}-0.164 \\
(-1.51)\end{array}$ & $\begin{array}{l}0.080 \\
(0.38)\end{array}$ & $\begin{array}{c}0.021 \\
(0.10)\end{array}$ & $\begin{array}{l}0.040 \\
(0.20)\end{array}$ & $\begin{array}{l}0.130 \\
(0.60)\end{array}$ \\
\hline BANKCR $^{*}(1-\mathrm{SEAS})$ & $\begin{array}{c}0.448^{* * *} \\
(2.84)\end{array}$ & $\begin{array}{c}0.295^{*} \\
(1.78)\end{array}$ & $\begin{array}{c}0.458^{* * *} \\
(2.73)\end{array}$ & $\begin{array}{l}0.183 \\
(1.15)\end{array}$ & $\begin{array}{c}0.616^{*} \\
(1.94)\end{array}$ & $\begin{array}{c}0.773^{* * *} \\
(2.67)\end{array}$ & $\begin{array}{c}0.509^{*} \\
(1.69)\end{array}$ & $\begin{array}{c}0.624^{*} \\
(1.72)\end{array}$ \\
\hline TRVOL*SEAS & $\begin{array}{l}-0.090 \\
(-1.20)\end{array}$ & $\begin{array}{c}-0.130^{* *} \\
(-2.08)\end{array}$ & $\begin{array}{l}-0.082 \\
(-1.13)\end{array}$ & $\begin{array}{c}-0.312^{* * *} \\
(-4.71)\end{array}$ & $\begin{array}{l}0.109 \\
(0.83)\end{array}$ & $\begin{array}{c}0.202 \\
(1.53)\end{array}$ & $\begin{array}{l}0.073 \\
(0.41)\end{array}$ & $\begin{array}{l}0.142 \\
(0.96)\end{array}$ \\
\hline TRVOL*(1-SEAS) & $\begin{array}{c}0.116^{* * *} \\
(2.70)\end{array}$ & $\begin{array}{c}0.106^{* *} \\
(2.48)\end{array}$ & $\begin{array}{c}0.135^{* * *} \\
(2.99)\end{array}$ & $\begin{array}{c}0.105^{* *} \\
(2.44)\end{array}$ & $\begin{array}{l}0.065 \\
(0.72)\end{array}$ & $\begin{array}{c}0.093 \\
(1.11)\end{array}$ & $\begin{array}{l}0.042 \\
(0.46)\end{array}$ & $\begin{array}{l}0.072 \\
(0.76)\end{array}$ \\
\hline SID*SEAS & $\begin{array}{l}-0.022 \\
(-0.78)\end{array}$ & & $\begin{array}{l}-0.017 \\
(-0.62)\end{array}$ & $\begin{array}{l}0.015 \\
(0.73)\end{array}$ & $\begin{array}{l}-0.068 \\
(-0.89)\end{array}$ & & $\begin{array}{l}-0.067 \\
(-0.94)\end{array}$ & $\begin{array}{l}-0.070 \\
(-1.45)\end{array}$ \\
\hline SID $*(1-S E A S)$ & $\begin{array}{c}-0.034^{* *} \\
(-2.05)\end{array}$ & & $\begin{array}{l}-0.025 \\
(-1.51)\end{array}$ & $\begin{array}{l}-0.014 \\
(-0.90)\end{array}$ & $\begin{array}{c}-0.139 * * * \\
(-3.17)\end{array}$ & & $\begin{array}{c}-0.146^{* * *} \\
(-3.13)\end{array}$ & $\begin{array}{c}-0.128^{* * * *} \\
(-3.12)\end{array}$ \\
\hline WITHTAX*SEAS & & $\begin{array}{c}-0.234^{* *} \\
(-2.42)\end{array}$ & & & & $\begin{array}{l}-0.177 \\
(-0.44)\end{array}$ & & \\
\hline WITHTAX*(1-SEAS) & & $\begin{array}{c}-0.509 * * * \\
(-3.30)\end{array}$ & & & & $\begin{array}{c}-0.797^{* * *} * \\
(-3.01)\end{array}$ & & \\
\hline ONSHORE*SIZE*SEAS & & & $\begin{array}{l}0.100 \\
(1.46)\end{array}$ & & & & $\begin{array}{l}-0.257 \\
(-1.30)\end{array}$ & \\
\hline ONSHORE*SIZE*(1-SEAS) & & & $\begin{array}{l}0.122 \\
(0.75)\end{array}$ & & & & $\begin{array}{l}5.501^{*} \\
(1.70)\end{array}$ & \\
\hline DERIV*SEAS & & & & $\begin{array}{c}0.057^{* *} \\
(2.19)\end{array}$ & & & & $\begin{array}{l}0.026 \\
(0.44)\end{array}$ \\
\hline DERIV*(1-SEAS) & & & & $\begin{array}{c}0.246^{* * *} \\
(3.53)\end{array}$ & & & & $\begin{array}{l}-0.026 \\
(-0.23)\end{array}$ \\
\hline Observations & 39,223 & 39,223 & 39,223 & 36,144 & 3,617 & 3,617 & 3,617 & 3,075 \\
\hline Number of firms & 4,163 & 4,163 & 4,163 & 4,038 & 509 & 509 & 509 & 468 \\
\hline Pseudo R-squared & 0.58 & 0.58 & 0.58 & 0.58 & 0.57 & 0.57 & 0.57 & 0.57 \\
\hline
\end{tabular}

Notes: The table reports the effects of the variables listed on the probability to issue bonds by a Probit model. The dependent variable is a dummy that equals one if the firm is a bond issuer, and zero otherwise. $S E A S$ is a dummy variable that equals one if the firm has previously issued in either the domestic or the foreign market, and zero otherwise. All models include firm-specific controls and time fixed effects. Robust z-statistics are in parentheses. Standard errors are clustered at the firm level. All firm-specific variables are lagged one period. *significant at $10 \%$; ${ }^{*}$ significant at $5 \%$; *** significant at $1 \%$. 


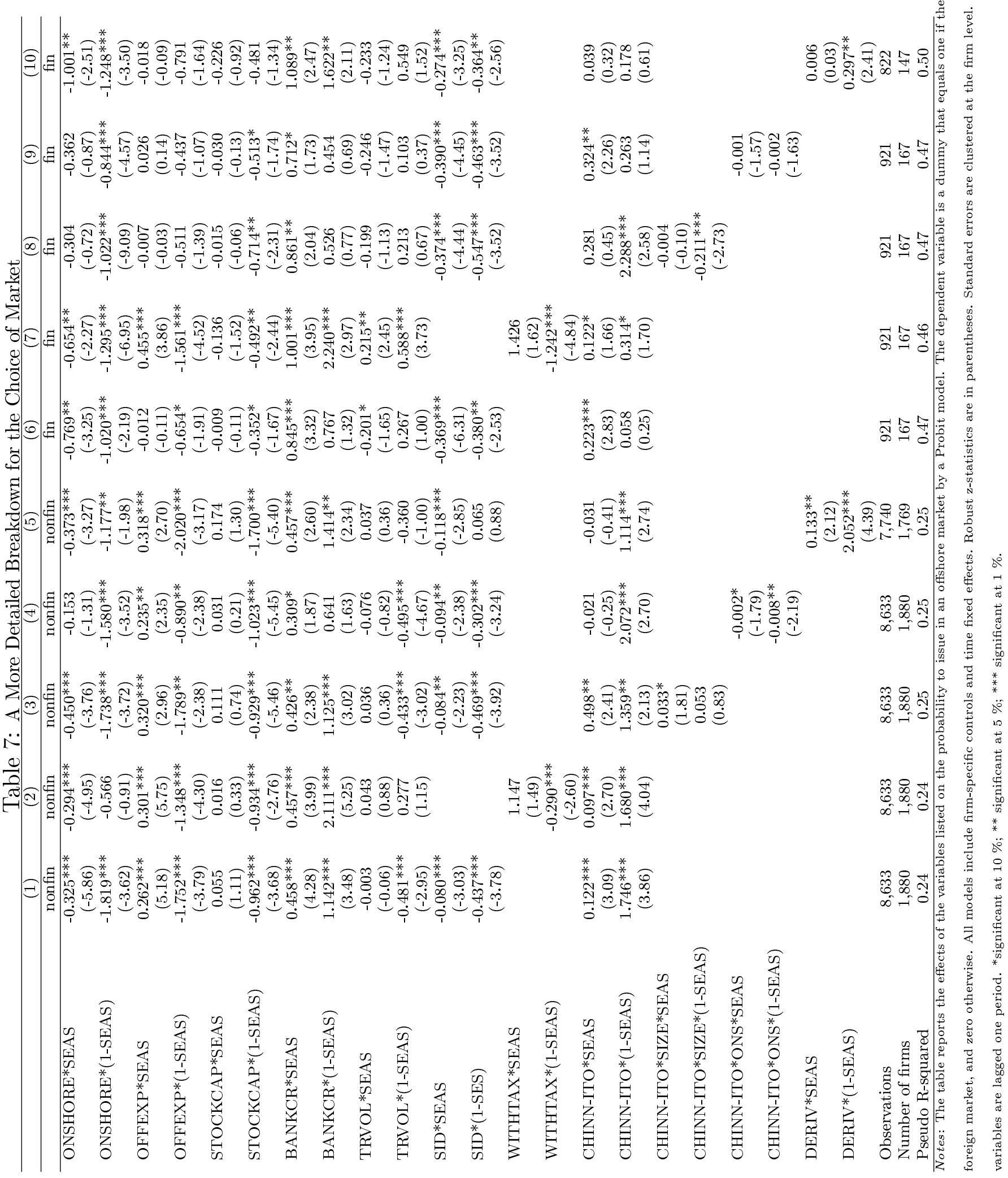


Table 8: Linear IV Probit-Bond Issuance Decision

\begin{tabular}{|c|c|c|c|c|c|}
\hline & $(1)$ & $(2)$ & $(3)$ & $(4)$ & $(5)$ \\
\hline PREVDOM & $\begin{array}{c}0.582^{* * *} \\
(36.10)\end{array}$ & $\begin{array}{c}0.557^{* * *} \\
(32.92)\end{array}$ & $\begin{array}{c}0.557^{* * *} \\
(32.93)\end{array}$ & $\begin{array}{c}0.557^{* * *} \\
(32.87)\end{array}$ & $\begin{array}{c}0.558^{* * *} \\
(32.03)\end{array}$ \\
\hline PREVFOR & $\begin{array}{c}0.321^{* * *} \\
(10.22)\end{array}$ & $\begin{array}{c}0.318^{* * *} \\
(10.18)\end{array}$ & $\begin{array}{c}0.318^{* * *} \\
(10.15)\end{array}$ & $\begin{array}{c}0.319^{* * *} \\
(10.18)\end{array}$ & $\begin{array}{c}0.320^{* * *} \\
(10.04)\end{array}$ \\
\hline ONSHORE & & $\begin{array}{l}-0.002 \\
(-0.18)\end{array}$ & $\begin{array}{l}0.002 \\
(0.27)\end{array}$ & $\begin{array}{l}-0.011 \\
(-1.14)\end{array}$ & $\begin{array}{l}0.005 \\
(0.55)\end{array}$ \\
\hline OFFEXP & & $\begin{array}{c}0.033^{* * *} \\
(4.48)\end{array}$ & $\begin{array}{c}0.039^{* * *} \\
(4.70)\end{array}$ & $\begin{array}{c}0.031^{* * *} \\
(4.10)\end{array}$ & $\begin{array}{c}0.029^{* * *} \\
(3.68)\end{array}$ \\
\hline STOCKCAP & & $\begin{array}{l}-0.009 \\
(-0.94)\end{array}$ & $\begin{array}{l}-0.013 \\
(-1.41)\end{array}$ & $\begin{array}{l}-0.007 \\
(-0.77)\end{array}$ & $\begin{array}{l}-0.013 \\
(-1.46)\end{array}$ \\
\hline TRVOL & & $\begin{array}{c}0.012^{* *} \\
(2.00)\end{array}$ & $\begin{array}{c}0.015^{* * *} \\
(2.75)\end{array}$ & $\begin{array}{c}0.014^{* *} \\
(2.30)\end{array}$ & $\begin{array}{l}0.011^{*} \\
(1.72)\end{array}$ \\
\hline BANKCR & & $\begin{array}{l}-0.008 \\
(-0.64)\end{array}$ & $\begin{array}{l}-0.009 \\
(-0.54)\end{array}$ & $\begin{array}{l}-0.003 \\
(-0.26)\end{array}$ & $\begin{array}{l}-0.005 \\
(-0.40)\end{array}$ \\
\hline SID & & $\begin{array}{c}-0.007^{* *} \\
(-2.39)\end{array}$ & & $\begin{array}{c}-0.006^{* *} \\
(-1.97)\end{array}$ & $\begin{array}{l}-0.003 \\
(-1.09)\end{array}$ \\
\hline WITHTAX & & & $\begin{array}{c}-0.031^{* *} \\
(-2.15)\end{array}$ & & \\
\hline ONSHORE*SIZE & & & & $\begin{array}{l}0.016 \\
(1.37)\end{array}$ & \\
\hline DERIV & & & & & $\begin{array}{c}0.007^{* *} \\
(2.04)\end{array}$ \\
\hline SIZE & $\begin{array}{c}0.012^{* * *} \\
(5.91)\end{array}$ & $\begin{array}{c}0.015^{* * *} \\
(5.62)\end{array}$ & $\begin{array}{c}0.016^{* * *} \\
(5.27)\end{array}$ & $\begin{array}{c}0.014^{* * *} \\
(4.87)\end{array}$ & $\begin{array}{c}0.016^{* * *} \\
(5.35)\end{array}$ \\
\hline INVA & $\begin{array}{l}0.042 \\
(0.31)\end{array}$ & $\begin{array}{l}0.173 \\
(1.03)\end{array}$ & $\begin{array}{c}0.182 \\
(1.07)\end{array}$ & $\begin{array}{l}0.161 \\
(0.96)\end{array}$ & $\begin{array}{l}0.267 \\
(1.37)\end{array}$ \\
\hline LEVER & $\begin{array}{c}0.333^{* * *} \\
(4.62)\end{array}$ & $\begin{array}{c}0.494^{* * *} \\
(3.82)\end{array}$ & $\begin{array}{c}0.494^{* * *} \\
(3.80)\end{array}$ & $\begin{array}{c}0.489^{* * *} \\
(3.80)\end{array}$ & $\begin{array}{c}0.570^{* * *} \\
(3.92)\end{array}$ \\
\hline PROF & $\begin{array}{c}-0.209^{* * *} \\
(-2.70)\end{array}$ & $\begin{array}{l}-0.109 \\
(-1.20)\end{array}$ & $\begin{array}{l}-0.112 \\
(-1.23)\end{array}$ & $\begin{array}{l}-0.108 \\
(-1.20)\end{array}$ & $\begin{array}{l}-0.098 \\
(-1.03)\end{array}$ \\
\hline COLL & $\begin{array}{l}-0.125 \\
(-0.56)\end{array}$ & $\begin{array}{l}-0.429 \\
(-1.21)\end{array}$ & $\begin{array}{l}-0.446 \\
(-1.24)\end{array}$ & $\begin{array}{l}-0.404 \\
(-1.14)\end{array}$ & $\begin{array}{l}-0.631 \\
(-1.53)\end{array}$ \\
\hline Observations & 32,119 & 32,119 & 32,119 & 32,119 & 30,497 \\
\hline Number of firms & 4,033 & 4,033 & 4,033 & 4,033 & 3,838 \\
\hline R-squared & 0.55 & 0.55 & 0.55 & 0.55 & 0.54 \\
\hline Sargan & 0.10 & 0.15 & 0.13 & 0.18 & 0.19 \\
\hline Kleibergen-Paap & 0.00 & 0.00 & 0.00 & 0.00 & 0.00 \\
\hline
\end{tabular}

Notes: The table reports the effects of the variables listed on the probability to issue bonds by a linear IV Probit model. Instruments are the firm-level variables, lagged twice or more. All models include time fixed effects. Robust z-statistics are in parentheses. Standard errors are clustered at the firm level. Sargan is a test of overidentifying restrictions, distributed as chi-square under the null of instrument validity. The Kleibergen-Paap test is an underidentification test, which tests whether the instruments are adequate to identify the equation. *significant at $10 \%$;* significant at $5 \%$; *** significant at $1 \%$. 
Table 9: Linear IV Probit-Choice of Market

\begin{tabular}{|c|c|c|c|c|c|c|}
\hline & (1) & $(2)$ & (3) & $(4)$ & $(5)$ & $(6)$ \\
\hline ONSHORE & & $\begin{array}{c}-0.125^{* * *} \\
(-4.74)\end{array}$ & $\begin{array}{c}-0.126^{* * *} \\
(-5.55)\end{array}$ & $\begin{array}{c}-0.081^{* * *} \\
(-3.11)\end{array}$ & $\begin{array}{c}-0.161^{* * *} \\
(-6.26)\end{array}$ & $\begin{array}{c}-0.142^{* * *} \\
(-5.65)\end{array}$ \\
\hline OFFEXP & & $\begin{array}{c}0.045^{* * *} \\
(2.70)\end{array}$ & $\begin{array}{c}0.051^{* * *} \\
(2.76)\end{array}$ & $\begin{array}{c}0.036^{* *} \\
(2.25)\end{array}$ & $\begin{array}{c}0.072^{* * *} \\
(3.65)\end{array}$ & $\begin{array}{c}0.065^{* * *} \\
(2.98)\end{array}$ \\
\hline STOCKCAP & & $\begin{array}{l}0.027 \\
(0.74)\end{array}$ & $\begin{array}{l}0.010 \\
(0.26)\end{array}$ & $\begin{array}{l}0.016 \\
(0.42)\end{array}$ & $\begin{array}{l}0.041 \\
(1.14)\end{array}$ & $\begin{array}{c}0.032 \\
(0.97)\end{array}$ \\
\hline TRVOL & & $\begin{array}{l}-0.016 \\
(-0.69)\end{array}$ & $\begin{array}{l}0.017 \\
(0.82)\end{array}$ & $\begin{array}{l}-0.036 \\
(-1.55)\end{array}$ & $\begin{array}{l}-0.005 \\
(-0.22)\end{array}$ & $\begin{array}{l}-0.013 \\
(-0.64)\end{array}$ \\
\hline BANKCR & & $\begin{array}{c}0.228^{* * *} \\
(6.21)\end{array}$ & $\begin{array}{c}0.283^{* * *} \\
(6.01)\end{array}$ & $\begin{array}{c}0.194^{* * *} \\
(5.29)\end{array}$ & $\begin{array}{c}0.207^{* * *} \\
(5.49)\end{array}$ & $\begin{array}{c}0.222^{* * *} \\
(5.85)\end{array}$ \\
\hline SID & & $\begin{array}{c}-0.037^{* * *} \\
(-5.09)\end{array}$ & & $\begin{array}{c}-0.041^{* * *} \\
(-5.27)\end{array}$ & $\begin{array}{c}-0.038^{* * *} \\
(-5.44)\end{array}$ & $\begin{array}{c}-0.045^{* * *} \\
(-5.87)\end{array}$ \\
\hline WITHTAX & & & $\begin{array}{c}-0.087^{*} \\
(-1.91)\end{array}$ & & & \\
\hline CHINN-ITO & $\begin{array}{c}0.115^{* * *} \\
(2.59)\end{array}$ & $\begin{array}{l}-0.001 \\
(-0.08)\end{array}$ & $\begin{array}{l}0.010 \\
(0.98)\end{array}$ & $\begin{array}{c}0.026^{*} \\
(1.93)\end{array}$ & $\begin{array}{c}0.133^{* * *} \\
(2.71)\end{array}$ & $\begin{array}{c}0.017 \\
(1.31)\end{array}$ \\
\hline CHINN-ITO*ONSHORE & & & & $\begin{array}{c}-0.001^{* * *} \\
(-2.71)\end{array}$ & & \\
\hline CHINN-ITO*SIZE & & & & & $\begin{array}{c}0.011^{* * *} \\
(2.67)\end{array}$ & \\
\hline DERIV & & & & & & $\begin{array}{l}-0.017 \\
(-1.42)\end{array}$ \\
\hline MATDUM & & $\begin{array}{c}0.043^{* *} \\
(2.47)\end{array}$ & $\begin{array}{c}0.050^{* * *} \\
(2.80)\end{array}$ & $\begin{array}{c}0.042^{* *} \\
(2.42)\end{array}$ & $\begin{array}{c}0.048^{* * *} \\
(2.75)\end{array}$ & $\begin{array}{c}0.049^{* * *} \\
(2.78)\end{array}$ \\
\hline SIZE & $\begin{array}{l}0.029^{*} \\
(1.92)\end{array}$ & $\begin{array}{c}0.033^{* * *} \\
(4.42)\end{array}$ & $\begin{array}{c}0.033^{* * *} \\
(4.17)\end{array}$ & $\begin{array}{c}0.034^{* * *} \\
(4.53)\end{array}$ & $\begin{array}{c}0.021^{* *} \\
(2.42)\end{array}$ & $\begin{array}{c}0.032^{* * *} \\
(4.20)\end{array}$ \\
\hline INVA & $\begin{array}{c}2.742 \\
(1.56)\end{array}$ & $\begin{array}{l}-0.215 \\
(-0.55)\end{array}$ & $\begin{array}{l}-0.471 \\
(-1.18)\end{array}$ & $\begin{array}{l}-0.214 \\
(-0.55)\end{array}$ & $\begin{array}{l}-0.205 \\
(-0.53)\end{array}$ & $\begin{array}{l}-0.231 \\
(-0.55)\end{array}$ \\
\hline LEVER & $\begin{array}{c}0.928^{* *} \\
(1.98)\end{array}$ & $\begin{array}{l}-0.136 \\
(-0.65)\end{array}$ & $\begin{array}{l}-0.327 \\
(-1.23)\end{array}$ & $\begin{array}{l}-0.156 \\
(-0.74)\end{array}$ & $\begin{array}{l}-0.126 \\
(-0.60)\end{array}$ & $\begin{array}{l}-0.121 \\
(-0.56)\end{array}$ \\
\hline PROF & $\begin{array}{l}-0.152 \\
(-0.41)\end{array}$ & $\begin{array}{l}-0.240 \\
(-0.92)\end{array}$ & $\begin{array}{l}-0.227 \\
(-1.17)\end{array}$ & $\begin{array}{l}-0.287 \\
(-1.09)\end{array}$ & $\begin{array}{l}-0.202 \\
(-0.77)\end{array}$ & $\begin{array}{l}-0.223 \\
(-0.82)\end{array}$ \\
\hline COLL & $\begin{array}{l}-4.624 \\
(-1.63)\end{array}$ & $\begin{array}{c}0.399 \\
(0.50)\end{array}$ & $\begin{array}{l}0.928 \\
(1.15)\end{array}$ & $\begin{array}{l}0.407 \\
(0.51)\end{array}$ & $\begin{array}{l}0.362 \\
(0.45)\end{array}$ & $\begin{array}{c}0.419 \\
(0.49)\end{array}$ \\
\hline Observations & 9,226 & 9,226 & 9,226 & 9,226 & 9,226 & 8,866 \\
\hline Number of firms & 1,021 & 1,021 & 1,021 & 1,021 & 1,021 & 980 \\
\hline R-squared & 0.13 & 0.15 & 0.12 & 0.15 & 0.17 & 0.16 \\
\hline Sargan & 0.75 & 0.47 & 0.06 & 0.46 & 0.56 & 0.48 \\
\hline Kleibergen-Paap & 0.00 & 0.09 & 0.00 & 0.00 & 0.00 & 0.00 \\
\hline
\end{tabular}

Notes: The table reports the effects of the variables listed on the probability to issue bonds by a linear IV Probit model. Instruments are the firm-level variables, lagged twice or more. Sargan is a test of overidentifying restrictions, distributed as chi-square under the null of instrument validity. The Kleibergen-Paap test is an underidentification test, which tests whether the instruments are adequate to identify the equation. All models include time fixed effects. Robust z-statistics are in parentheses. Standard errors are clustered at the firm level. *significant at $10 \% ; * *$ significant at $5 \%$;** significant at $1 \%$. 
Table 10: Bond Issuance Decision-Removing Hong Kong and Singapore

\begin{tabular}{|c|c|c|c|c|c|}
\hline & (1) & $(2)$ & (3) & $(4)$ & $(5)$ \\
\hline PREVDOM & $\begin{array}{c}2.760^{* * *} \\
(110.86)\end{array}$ & $\begin{array}{c}2.677^{* * *} \\
(107.40)\end{array}$ & $\begin{array}{c}2.678^{* * *} \\
(107.50)\end{array}$ & $\begin{array}{c}2.678^{* * *} \\
(107.22)\end{array}$ & $\begin{array}{c}2.690^{* * *} \\
(102.13)\end{array}$ \\
\hline PREVFOR & $\begin{array}{c}1.164^{* * *} \\
(22.11)\end{array}$ & $\begin{array}{c}1.148^{* * *} \\
(21.44)\end{array}$ & $\begin{array}{c}1.148^{* * *} \\
(21.44)\end{array}$ & $\begin{array}{c}1.148^{* * *} \\
(21.43)\end{array}$ & $\begin{array}{c}1.146^{* * *} \\
(20.59)\end{array}$ \\
\hline ONSHORE & & $\begin{array}{l}0.052 \\
(1.37)\end{array}$ & $\begin{array}{c}0.043 \\
(1.16)\end{array}$ & $\begin{array}{l}0.081 \\
(1.51)\end{array}$ & $\begin{array}{l}0.046 \\
(0.94)\end{array}$ \\
\hline OFFEXP & & $\begin{array}{c}0.098^{* * *} \\
(4.38)\end{array}$ & $\begin{array}{c}0.085^{* * *} \\
(2.70)\end{array}$ & $\begin{array}{c}0.098^{* * *} \\
(4.41)\end{array}$ & $\begin{array}{c}0.112^{* * *} \\
(4.66)\end{array}$ \\
\hline STOCKCAP & & $\begin{array}{c}-0.095^{* * *} \\
(-2.86)\end{array}$ & $\begin{array}{c}-0.124^{* * *} \\
(-4.02)\end{array}$ & $\begin{array}{c}-0.106^{* * *} \\
(-2.97)\end{array}$ & $\begin{array}{c}-0.088^{* *} \\
(-2.26)\end{array}$ \\
\hline BANKCR & & $\begin{array}{l}0.100 \\
(1.36)\end{array}$ & $\begin{array}{c}0.205^{* *} \\
(2.32)\end{array}$ & $\begin{array}{c}0.074 \\
(0.92)\end{array}$ & $\begin{array}{l}0.113 \\
(1.39)\end{array}$ \\
\hline TRVOL & & $\begin{array}{l}0.006 \\
(0.23)\end{array}$ & $\begin{array}{c}0.049^{* *} \\
(1.96)\end{array}$ & $\begin{array}{l}-0.004 \\
(-0.13)\end{array}$ & $\begin{array}{l}-0.001 \\
(-0.00)\end{array}$ \\
\hline SID & & $\begin{array}{c}-0.028^{* *} \\
(-2.17)\end{array}$ & & $\begin{array}{c}-0.031^{* *} \\
(-2.28)\end{array}$ & $\begin{array}{c}-0.028^{* *} \\
(-2.12)\end{array}$ \\
\hline WITHTAX & & & $\begin{array}{l}-0.066 \\
(-0.79)\end{array}$ & & \\
\hline ONSHORE*SIZE & & & & $\begin{array}{l}-0.041 \\
(-0.82)\end{array}$ & \\
\hline DERIV & & & & & $\begin{array}{c}0.006^{* *} \\
(2.29)\end{array}$ \\
\hline SIZE & $\begin{array}{c}0.117^{* * *} \\
(24.63)\end{array}$ & $\begin{array}{c}0.115^{* * *} \\
(17.77)\end{array}$ & $\begin{array}{c}0.113^{* * *} \\
(17.66)\end{array}$ & $\begin{array}{c}0.117^{* * *} \\
(16.27)\end{array}$ & $\begin{array}{c}0.116^{* * *} \\
(17.15)\end{array}$ \\
\hline INVA & $\begin{array}{c}-0.235^{* * *} \\
(-3.74)\end{array}$ & $\begin{array}{c}-0.146^{* *} \\
(-2.30)\end{array}$ & $\begin{array}{c}-0.144^{* *} \\
(-2.27)\end{array}$ & $\begin{array}{c}-0.145^{* *} \\
(-2.29)\end{array}$ & $\begin{array}{c}-0.124^{*} \\
(-1.85)\end{array}$ \\
\hline LEVER & $\begin{array}{c}1.123^{* * *} \\
(11.59)\end{array}$ & $\begin{array}{c}1.433^{* * *} \\
(13.76)\end{array}$ & $\begin{array}{c}1.439^{* * *} \\
(13.82)\end{array}$ & $\begin{array}{c}1.428^{* * *} \\
(13.69)\end{array}$ & $\begin{array}{c}1.588^{* * *} \\
(14.42)\end{array}$ \\
\hline PROF & $\begin{array}{c}-1.496^{* * *} \\
(-10.04)\end{array}$ & $\begin{array}{c}-1.147^{* * *} \\
(-7.47)\end{array}$ & $\begin{array}{c}-1.136^{* * *} \\
(-7.40)\end{array}$ & $\begin{array}{c}-1.147^{* * *} \\
(-7.47)\end{array}$ & $\begin{array}{c}-1.123^{* * *} \\
(-6.79)\end{array}$ \\
\hline COLL & $\begin{array}{l}0.176 \\
(1.59)\end{array}$ & $\begin{array}{l}0.043 \\
(0.38)\end{array}$ & $\begin{array}{l}0.042 \\
(0.37)\end{array}$ & $\begin{array}{l}0.043 \\
(0.38)\end{array}$ & $\begin{array}{l}-0.021 \\
(-0.17)\end{array}$ \\
\hline Observations & 31,355 & 31,307 & 31,307 & 31,307 & 28,829 \\
\hline Number of firms & 3,485 & 3,484 & 3,484 & 3,484 & 3,371 \\
\hline Pseudo R-squared & 0.56 & 0.56 & 0.56 & 0.56 & 0.57 \\
\hline
\end{tabular}

Notes: The table reports the effects of the variables listed on the probability to issue bonds by a Probit model. The dependent variable is a dummy that equals one if the firm is a bond issuer, and zero otherwise. All models include time fixed effects. Robust z-statistics are in parentheses. Standard errors are clustered at the firm level. All firm-specific variables are lagged one period. *significant at $10 \%$;* significant at $5 \%$;** significant at $1 \%$. 
Table 11: Choice of Market-Removing Hong Kong and Singapore

\begin{tabular}{|c|c|c|c|c|c|c|}
\hline & $(1)$ & $(2)$ & $(3)$ & $(4)$ & $(5)$ & $(6)$ \\
\hline ONSHORE & & $\begin{array}{c}-0.249^{* * *} \\
(-3.83)\end{array}$ & $\begin{array}{c}-0.294^{* * *} \\
(-4.10)\end{array}$ & $\begin{array}{c}-0.195^{* * *} \\
(-2.74)\end{array}$ & $\begin{array}{c}-0.278^{* * *} \\
(-3.94)\end{array}$ & $\begin{array}{l}-0.103 \\
(-1.26)\end{array}$ \\
\hline OFFEXP & & $\begin{array}{c}0.092 \\
(1.40)\end{array}$ & $\begin{array}{c}0.173^{* *} \\
(2.10)\end{array}$ & $\begin{array}{l}0.096 \\
(1.43)\end{array}$ & $\begin{array}{l}0.114 \\
(1.62)\end{array}$ & $\begin{array}{c}0.066 \\
(1.12)\end{array}$ \\
\hline STOCKCAP & & $\begin{array}{c}-0.248^{* *} \\
(-2.49)\end{array}$ & $\begin{array}{c}-0.186^{*} \\
(-1.95)\end{array}$ & $\begin{array}{c}-0.228^{* *} \\
(-2.52)\end{array}$ & $\begin{array}{c}-0.251^{* *} \\
(-2.54)\end{array}$ & $\begin{array}{c}-0.294^{* *} \\
(-2.54)\end{array}$ \\
\hline BANKCR & & $\begin{array}{c}0.279^{* *} \\
(2.38)\end{array}$ & $\begin{array}{c}0.114 \\
(1.03)\end{array}$ & $\begin{array}{c}0.210^{* *} \\
(1.96)\end{array}$ & $\begin{array}{c}0.305^{* *} \\
(2.57)\end{array}$ & $\begin{array}{c}0.131 \\
(1.37)\end{array}$ \\
\hline TRVOL & & $\begin{array}{c}0.004 \\
(0.09)\end{array}$ & $\begin{array}{l}-0.019 \\
(-0.34)\end{array}$ & $\begin{array}{l}-0.034 \\
(-0.64)\end{array}$ & $\begin{array}{l}0.020 \\
(0.40)\end{array}$ & $\begin{array}{l}-0.058 \\
(-1.20)\end{array}$ \\
\hline SID & & $\begin{array}{c}0.016 \\
(0.78)\end{array}$ & & $\begin{array}{l}-0.008 \\
(-0.42)\end{array}$ & $\begin{array}{c}0.024 \\
(1.07)\end{array}$ & $\begin{array}{l}-0.003 \\
(-0.15)\end{array}$ \\
\hline WITHTAX & & & $\begin{array}{c}-0.265^{* *} \\
(-2.42)\end{array}$ & & & \\
\hline CHINN-ITO & $\begin{array}{c}0.081 \\
(1.58)\end{array}$ & $\begin{array}{c}0.072^{* *} \\
(2.39)\end{array}$ & $\begin{array}{c}0.037 \\
(1.10)\end{array}$ & $\begin{array}{l}0.013 \\
(0.25)\end{array}$ & $\begin{array}{c}0.376 \\
(1.45)\end{array}$ & $\begin{array}{l}0.025 \\
(0.67)\end{array}$ \\
\hline CHINN-ITO*ONSHORE & & & & $\begin{array}{c}-0.002 * \\
(-1.74)\end{array}$ & & \\
\hline CHINN-ITO*SIZE & & & & & $\begin{array}{c}0.024 \\
(1.18)\end{array}$ & \\
\hline DERIV & & & & & & $\begin{array}{c}0.131^{* *} \\
(2.08)\end{array}$ \\
\hline MATDUM & & $\begin{array}{c}0.220^{* * *} \\
(3.24)\end{array}$ & $\begin{array}{c}0.219 * * * \\
(3.23)\end{array}$ & $\begin{array}{c}0.213^{* * *} \\
(3.12)\end{array}$ & $\begin{array}{c}0.228^{* * *} \\
(3.32)\end{array}$ & $\begin{array}{c}0.240^{* * *} \\
(3.36)\end{array}$ \\
\hline SIZE & $\begin{array}{c}0.042^{*} \\
(1.72)\end{array}$ & $\begin{array}{c}0.088^{* * *} \\
(2.81)\end{array}$ & $\begin{array}{c}0.088^{* * *} \\
(2.85)\end{array}$ & $\begin{array}{c}0.086^{* * *} \\
(2.77)\end{array}$ & $\begin{array}{c}0.085^{* * *} \\
(2.75)\end{array}$ & $\begin{array}{c}0.086^{* * *} \\
(2.68)\end{array}$ \\
\hline INVA & $\begin{array}{l}-0.268 \\
(-1.00)\end{array}$ & $\begin{array}{l}-0.304 \\
(-1.14)\end{array}$ & $\begin{array}{l}-0.299 \\
(-1.13)\end{array}$ & $\begin{array}{l}-0.307 \\
(-1.15)\end{array}$ & $\begin{array}{l}-0.321 \\
(-1.20)\end{array}$ & $\begin{array}{l}-0.337 \\
(-1.23)\end{array}$ \\
\hline LEVER & $\begin{array}{c}1.323^{* * *} \\
(3.42)\end{array}$ & $\begin{array}{c}0.518 \\
(1.31)\end{array}$ & $\begin{array}{c}0.516 \\
(1.31)\end{array}$ & $\begin{array}{l}0.490 \\
(1.24)\end{array}$ & $\begin{array}{l}0.480 \\
(1.20)\end{array}$ & $\begin{array}{c}0.493 \\
(1.22)\end{array}$ \\
\hline PROF & $\begin{array}{l}0.917 \\
(1.64)\end{array}$ & $\begin{array}{c}0.177 \\
(0.30)\end{array}$ & $\begin{array}{l}0.167 \\
(0.28)\end{array}$ & $\begin{array}{l}0.146 \\
(0.25)\end{array}$ & $\begin{array}{l}0.145 \\
(0.24)\end{array}$ & $\begin{array}{l}-0.024 \\
(-0.04)\end{array}$ \\
\hline COLL & $\begin{array}{l}0.163 \\
(0.36)\end{array}$ & $\begin{array}{c}0.592 \\
(1.29)\end{array}$ & $\begin{array}{l}0.583 \\
(1.28)\end{array}$ & $\begin{array}{l}0.605 \\
(1.32)\end{array}$ & $\begin{array}{c}0.612 \\
(1.33)\end{array}$ & $\begin{array}{l}0.647 \\
(1.37)\end{array}$ \\
\hline Observations & 9,551 & 9,538 & 9,538 & 9,538 & 9,538 & 8,879 \\
\hline Number of firms & 916 & 916 & 916 & 916 & 916 & 899 \\
\hline Pseudo R-squared & 0.03 & 0.07 & 0.07 & 0.07 & 0.07 & 0.08 \\
\hline
\end{tabular}

Notes: The table reports the effects of the variables listed on the probability to issue in a foreign market by a Probit model. The dependent variable is a dummy that equals one if the firm issues in a foreign market, and zero otherwise. All models include time fixed effects. Robust z-statistics are in parentheses. Standard errors are clustered at the firm level. All firm-specific variables are lagged one period. *significant at $10 \%$;* significant at $5 \%$; ** significant at $1 \%$. 
Table 12: Bond Issuance Decision-Double Clustering

\begin{tabular}{|c|c|c|c|c|c|}
\hline & $(1)$ & $(2)$ & (3) & $(4)$ & $(5)$ \\
\hline PREVDOM & $\begin{array}{c}2.512^{* * *} \\
(53.41)\end{array}$ & $\begin{array}{c}2.460^{* * *} \\
(52.05)\end{array}$ & $\begin{array}{c}2.458^{* * *} \\
(51.97)\end{array}$ & $\begin{array}{c}2.459^{* * *} \\
(51.91)\end{array}$ & $\begin{array}{c}2.464^{* * *} \\
(51.75)\end{array}$ \\
\hline PREVFOR & $\begin{array}{c}1.523^{* * *} \\
(20.01)\end{array}$ & $\begin{array}{c}1.507^{* * *} \\
(19.34)\end{array}$ & $\begin{array}{c}1.500 * * * \\
(19.21)\end{array}$ & $\begin{array}{c}1.507^{* * *} \\
(19.34)\end{array}$ & $\begin{array}{c}1.536^{* * *} \\
(18.75)\end{array}$ \\
\hline ONSHORE & & $\begin{array}{c}-0.107^{* * *} \\
(-3.82)\end{array}$ & $\begin{array}{l}-0.034 \\
(-1.20)\end{array}$ & $\begin{array}{c}-0.140^{* * *} \\
(-4.64)\end{array}$ & $\begin{array}{c}-0.081^{* * *} \\
(-2.75)\end{array}$ \\
\hline OFFEXP & & $\begin{array}{c}0.189^{* * *} \\
(14.70)\end{array}$ & $\begin{array}{c}0.226^{* * *} \\
(15.95)\end{array}$ & $\begin{array}{c}0.183^{* * *} \\
(13.82)\end{array}$ & $\begin{array}{c}0.177^{* * *} \\
(10.98)\end{array}$ \\
\hline STOCKCAP & & $\begin{array}{l}0.018 \\
(0.88)\end{array}$ & $\begin{array}{c}-0.045^{* *} \\
(-2.31)\end{array}$ & $\begin{array}{c}0.027 \\
(1.35)\end{array}$ & $\begin{array}{l}0.014 \\
(0.67)\end{array}$ \\
\hline BANKCR & & $\begin{array}{l}-0.022 \\
(-0.65)\end{array}$ & $\begin{array}{c}-0.094^{* * *} \\
(-2.64)\end{array}$ & $\begin{array}{l}-0.010 \\
(-0.34)\end{array}$ & $\begin{array}{l}-0.043 \\
(-1.15)\end{array}$ \\
\hline TRVOL & & $\begin{array}{c}0.099^{* * *} \\
(5.46)\end{array}$ & $\begin{array}{c}0.059^{* * *} \\
(2.92)\end{array}$ & $\begin{array}{c}0.107^{* * *} \\
(6.29)\end{array}$ & $\begin{array}{c}0.088^{* * *} \\
(4.48)\end{array}$ \\
\hline SID & & $\begin{array}{c}-0.026^{* * *} \\
(-4.19)\end{array}$ & & $\begin{array}{c}-0.024^{* * *} \\
(-4.00)\end{array}$ & $\begin{array}{c}-0.024^{* * *} \\
(-3.49)\end{array}$ \\
\hline WITHTAX & & & $\begin{array}{c}-0.276^{* * *} \\
(-5.45)\end{array}$ & & \\
\hline ONSHORE*SIZE & & & & $\begin{array}{c}0.058 \\
(1.61)\end{array}$ & \\
\hline DERIV & & & & & $\begin{array}{c}0.000^{* *} \\
(2.09)\end{array}$ \\
\hline SIZE & $\begin{array}{c}0.074^{* * *} \\
(13.27)\end{array}$ & $\begin{array}{c}0.087^{* * *} \\
(12.98)\end{array}$ & $\begin{array}{c}0.095^{* * *} \\
(12.60)\end{array}$ & $\begin{array}{c}0.084^{* * *} \\
(11.46)\end{array}$ & $\begin{array}{c}0.088^{* * *} \\
(12.05)\end{array}$ \\
\hline INVA & $\begin{array}{c}-0.362^{* * *} \\
(-6.71)\end{array}$ & $\begin{array}{c}-0.207^{* * *} \\
(-4.45)\end{array}$ & $\begin{array}{c}-0.198^{* * *} \\
(-4.28)\end{array}$ & $\begin{array}{c}-0.205^{* * *} \\
(-4.42)\end{array}$ & $\begin{array}{c}-0.211^{* * *} \\
(-4.33)\end{array}$ \\
\hline LEVER & $\begin{array}{c}1.183^{* * *} \\
(11.87)\end{array}$ & $\begin{array}{c}1.439 * * * \\
(12.82)\end{array}$ & $\begin{array}{c}1.409^{* * *} \\
(12.71)\end{array}$ & $\begin{array}{c}1.448^{* * *} \\
(12.96)\end{array}$ & $\begin{array}{c}1.562^{* * *} \\
(12.97)\end{array}$ \\
\hline PROF & $\begin{array}{c}0.275^{* * *} \\
(2.90)\end{array}$ & $\begin{array}{l}0.079 \\
(0.90)\end{array}$ & $\begin{array}{l}0.081 \\
(0.93)\end{array}$ & $\begin{array}{l}0.075 \\
(0.87)\end{array}$ & $\begin{array}{l}0.043 \\
(0.48)\end{array}$ \\
\hline COLL & $\begin{array}{c}-1.118^{* * *} \\
(-5.00)\end{array}$ & $\begin{array}{c}-0.843^{* * *} \\
(-3.79)\end{array}$ & $\begin{array}{c}-0.895^{* * *} \\
(-4.05)\end{array}$ & $\begin{array}{c}-0.840^{* * *} \\
(-3.76)\end{array}$ & $\begin{array}{c}-0.804^{* * *} \\
(-3.81)\end{array}$ \\
\hline Observations & 42,888 & 42,840 & 42,840 & 42,840 & 39,219 \\
\hline Number of firms & 4,673 & 4,672 & 4,672 & 4,672 & 4,506 \\
\hline Pseudo R-squared & 0.54 & 0.55 & 0.55 & 0.55 & 0.55 \\
\hline
\end{tabular}

Notes: The table reports the effects of the variables listed on the probability to issue bonds by a Probit model. The dependent variable is a dummy that equals one if the firm is a bond issuer, and zero otherwise. All models include time fixed effects. Robust z-statistics are in parentheses. Standard errors are clustered at the firm and country level. All firm-specific variables are lagged one period. *significant at $10 \%$;* significant at $5 \% ; * * *$ significant at $1 \%$. 
Table 13: Choice of Market- Double Clustering

\begin{tabular}{|c|c|c|c|c|c|c|}
\hline & $(1)$ & $(2)$ & $(3)$ & $(4)$ & $(5)$ & $(6)$ \\
\hline ONSHORE & & $\begin{array}{c}-0.463^{* * *} \\
(-12.58)\end{array}$ & $\begin{array}{c}-0.428^{* * *} \\
(-10.62)\end{array}$ & $\begin{array}{c}-0.277^{* * *} \\
(-5.47)\end{array}$ & $\begin{array}{c}-0.539^{* * *} \\
(-13.11)\end{array}$ & $\begin{array}{c}-0.465^{* * *} \\
(-11.93)\end{array}$ \\
\hline OFFEXP & & $\begin{array}{c}0.150^{* * *} \\
(5.49)\end{array}$ & $\begin{array}{c}0.215^{* * *} \\
(7.81)\end{array}$ & $\begin{array}{c}0.116^{* * *} \\
(4.16)\end{array}$ & $\begin{array}{c}0.197^{* * *} \\
(6.51)\end{array}$ & $\begin{array}{c}0.178^{* * *} \\
(6.06)\end{array}$ \\
\hline STOCKCAP & & $\begin{array}{c}0.091^{* * *} \\
(2.81)\end{array}$ & $\begin{array}{l}0.029 \\
(0.86)\end{array}$ & $\begin{array}{l}0.040 \\
(1.19)\end{array}$ & $\begin{array}{c}0.131^{* * *} \\
(3.85)\end{array}$ & $\begin{array}{c}0.102^{* * *} \\
(2.82)\end{array}$ \\
\hline BANKCR & & $\begin{array}{c}0.719^{* * *} \\
(11.19)\end{array}$ & $\begin{array}{c}0.716^{* * *} \\
(10.95)\end{array}$ & $\begin{array}{c}0.589^{* * *} \\
(8.81)\end{array}$ & $\begin{array}{c}0.695^{* * *} \\
(10.68)\end{array}$ & $\begin{array}{c}0.683^{* * *} \\
(10.44)\end{array}$ \\
\hline TRVOL & & $\begin{array}{l}0.019 \\
(0.57)\end{array}$ & $\begin{array}{c}0.046 \\
(1.45)\end{array}$ & $\begin{array}{c}-0.067^{*} \\
(-1.82)\end{array}$ & $\begin{array}{l}0.048 \\
(1.40)\end{array}$ & $\begin{array}{l}0.002 \\
(0.06)\end{array}$ \\
\hline SID & & $\begin{array}{c}-0.075^{* * *} \\
(-5.16)\end{array}$ & & $\begin{array}{c}-0.095^{* * *} \\
(-6.28)\end{array}$ & $\begin{array}{c}-0.075^{* * *} \\
(-5.14)\end{array}$ & $\begin{array}{c}-0.087^{* * *} \\
(-5.34)\end{array}$ \\
\hline WITHTAX & & & $\begin{array}{c}-0.351^{* * *} \\
(-5.09)\end{array}$ & & & \\
\hline CHINN-ITO & $\begin{array}{c}0.217^{* * *} \\
(12.08)\end{array}$ & $\begin{array}{c}0.039^{*} \\
(1.83)\end{array}$ & $\begin{array}{c}0.041^{* *} \\
(1.99)\end{array}$ & $\begin{array}{c}0.144^{* * *} \\
(5.03)\end{array}$ & $\begin{array}{c}0.231^{* * *} \\
(3.75)\end{array}$ & $\begin{array}{c}0.068^{* *} \\
(2.44)\end{array}$ \\
\hline CHINN-ITO*ONSHORE & & & & $\begin{array}{c}-0.001^{* * *} \\
(-5.63)\end{array}$ & & \\
\hline CHINN-ITO*SIZE & & & & & $\begin{array}{c}0.023^{* * *} \\
(4.79)\end{array}$ & \\
\hline DERIV & & & & & & $\begin{array}{c}0.031^{* *} \\
(2.42)\end{array}$ \\
\hline MATDUM & & $\begin{array}{c}0.170^{* * *} \\
(5.57)\end{array}$ & $\begin{array}{c}0.167^{* * *} \\
(5.48)\end{array}$ & $\begin{array}{c}0.166^{* * *} \\
(5.43)\end{array}$ & $\begin{array}{c}0.178^{* * *} \\
(5.81)\end{array}$ & $\begin{array}{c}0.197^{* * *} \\
(6.22)\end{array}$ \\
\hline SIZE & $\begin{array}{c}0.031^{* * *} \\
(5.94)\end{array}$ & $\begin{array}{c}0.110^{* * *} \\
(15.28)\end{array}$ & $\begin{array}{c}0.115^{* * *} \\
(15.64)\end{array}$ & $\begin{array}{c}0.115^{* * *} \\
(15.75)\end{array}$ & $\begin{array}{c}0.086^{* * *} \\
(9.81)\end{array}$ & $\begin{array}{c}0.108^{* * *} \\
(14.40)\end{array}$ \\
\hline INVA & $\begin{array}{c}-0.235^{* * *} \\
(-2.66)\end{array}$ & $\begin{array}{c}-0.219^{* *} \\
(-2.55)\end{array}$ & $\begin{array}{c}-0.198^{* *} \\
(-2.32)\end{array}$ & $\begin{array}{c}-0.219^{* *} \\
(-2.55)\end{array}$ & $\begin{array}{c}-0.235^{* * *} \\
(-2.75)\end{array}$ & $\begin{array}{c}-0.268^{* * *} \\
(-2.97)\end{array}$ \\
\hline LEVER & $\begin{array}{c}0.903^{* * *} \\
(7.88)\end{array}$ & $\begin{array}{l}-0.083 \\
(-0.66)\end{array}$ & $\begin{array}{l}-0.101 \\
(-0.79)\end{array}$ & $\begin{array}{l}-0.135 \\
(-1.06)\end{array}$ & $\begin{array}{l}-0.105 \\
(-0.83)\end{array}$ & $\begin{array}{l}-0.091 \\
(-0.69)\end{array}$ \\
\hline PROF & $\begin{array}{c}0.663^{* * *} \\
(3.38)\end{array}$ & $\begin{array}{l}0.069 \\
(0.32)\end{array}$ & $\begin{array}{l}-0.012 \\
(-0.06)\end{array}$ & $\begin{array}{l}-0.005 \\
(-0.02)\end{array}$ & $\begin{array}{l}0.102 \\
(0.47)\end{array}$ & $\begin{array}{l}0.063 \\
(0.27)\end{array}$ \\
\hline COLL & $\begin{array}{l}-0.146 \\
(-0.98)\end{array}$ & $\begin{array}{c}0.356^{* *} \\
(2.40)\end{array}$ & $\begin{array}{c}0.328^{* *} \\
(2.22)\end{array}$ & $\begin{array}{c}0.384^{* * *} \\
(2.59)\end{array}$ & $\begin{array}{c}0.359^{* *} \\
(2.43)\end{array}$ & $\begin{array}{c}0.422^{* * *} \\
(2.71)\end{array}$ \\
\hline Observations & 11,881 & 11,868 & 11,868 & 11,868 & 11,868 & 11,036 \\
\hline Number of Firms & 1,095 & 1,095 & 1,095 & 1,095 & 1,095 & 1,076 \\
\hline Pseudo R-squared & 0.03 & 0.14 & 0.14 & 0.14 & 0.14 & 0.14 \\
\hline
\end{tabular}

Notes: The table reports the effects of the variables listed on the probability to issue in a foreign market by a Probit model. The dependent variable is a dummy that equals one if the firm issues in a foreign market, and zero otherwise. All models include time fixed effects. Robust z-statistics are in parentheses. Standard errors are clustered at the firm and country level. All firm-specific variables are lagged one period. *significant at $10 \%$;* significant at $5 \%$; *** significant at $1 \%$. 


\section{Appendix}

\section{Firm-Level Data (Source: Compustat Global)}

- Firm size (SIZE): logarithm of the firm's total assets.

- Firm investment over total assets (INVA): captures the expansion of the firm-and the greater need for financing.

- Leverage (LEVER): long-term debt over total assets.

- Profitability ratio $(P R O F)$ : earnings before interest and taxes relative to total assets; measures a firm's ability to generate profits.

- Collateral assets in total assets $(C O L L)$ : tangible assets over total assets.

- Previous issuance (PREVDOM): dummy variable that equals one if a firm had issued at any time in the domestic market in the past, and zero otherwise.

- Previous issuance (PREVFOR): dummy variable that equals one if a firm had issued at any time in the foreign market in the past, and zero otherwise.

- Maturity (MATDUM): dummy variable that equals one if a firm issues bonds with average maturity longer than 6 years (medium and long-term bonds), and zero otherwise.

- Seasoned $(S E A S)$ : dummy variable that equals one if a firm has issued at least once in the past, and zero otherwise. We use three-year initial sample to identify the seasoned issuers at the start of our estimation period.

\section{Market Development Data (Sources: BIS, WDI and AREAER)}

- Market size of the bond market using total debt securities outstanding in billions of USD at the end of each year in both onshore and offshore markets; uses revised figures from the Bank for International Settlements.

- Onshore market size (ONSHORE): logarithm of the size of the onshore market. It covers corporate (including financial) and sovereign bond issuance.

- Offshore market size $(O F F E X P)$ : logarithm of the size of the offshore market. It covers corporate (including financial) and sovereign bond issuance.

- Stock market size $(S T O C K C A P)$ : logarithm of the capitalization of the domestic stock market.

- Financial intermediary size $(B A N K C R)$ : logarithm of the the ratio of private bank credit to GDP.

- Bond market liquidity (TRVOL): logarithm of the value of local currency corporate bonds transacted in the secondary markets.

- Relative borrowing costs between markets: we use short-term interest differentials (SID): Shortinterest differentials between the annual averages of local and US nominal rates (LCY - US) on bonds of three- to twelve-month maturity in percentage points. 
- Dummy for withholding tax (WITHTAX) on foreign investors' holdings of local currency government bonds; dummy defined for each country and year drawn from Chan et al. (2011) and KPMG (2019).

- Size of foreign exchange swaps, derivative, and options market (DERIV): sum of currency swaps, FX swaps, options, outright forwards, and other derivatives based on the daily average turnover in April, by location of the counterparty, currency, and reporting country from the BIS Triennial Survey. We interpolate the intervening years using a semi-annual survey conducted by the BIS.

- Chinn-Ito index as a measure of capital market openness (CHINN - ITO): based on the binary dummy variables that codify the tabulation of restrictions on cross-border financial transactions reported in the IMF's Annual Report on Exchange Arrangements and Exchange Restrictions (AREAER). 
Table A.1: Test for the Equality of Coefficients Based on Results in Table 6

\begin{tabular}{lcccccccc}
\hline & $(1)$ & $(2)$ & $(3)$ & $(4)$ & $(5)$ & $(6)$ & $(7)$ & $(8)$ \\
\hline & nonfin & nonfin & nonfin & nonfin & fin & fin & fin & fin \\
\hline ONSHORE & 0.81 & 0.85 & 0.91 & 0.01 & 0.08 & 0.01 & 0.33 & 0.07 \\
OFFEXP & 0.00 & 0.00 & 0.00 & 0.00 & 0.98 & 0.05 & 0.07 & 0.42 \\
STOCKCAP & 0.00 & 0.00 & 0.00 & 0.00 & 0.00 & 0.30 & 0.26 & 0.06 \\
BANKCR & 0.00 & 0.00 & 0.00 & 0.09 & 0.11 & 0.02 & 0.19 & 0.20 \\
TRVOL & 0.00 & 0.00 & 0.00 & 0.75 & 0.80 & 0.18 & 0.87 & 0.65 \\
SID & 0.68 & & 0.78 & 0.21 & 0.35 & & 0.32 & 0.29 \\
WITHTAX & & 0.06 & & & & 0.00 & & \\
ONSHORE*SIZE & & & 0.89 & & & & 0.09 & \\
DERIV & & & & 0.00 & & & & 0.66 \\
\hline
\end{tabular}

Notes: The table reports p-values of a test statistic where the null hypothesis is the equality of the coefficients.

Table A.2: Test for the Equality of Coefficients Based on Results in Table 7

\begin{tabular}{lcccccccccc}
\hline & $(1)$ & $(2)$ & $(3)$ & $(4)$ & $(5)$ & $(6)$ & $(7)$ & $(8)$ & $(9)$ & $(10)$ \\
\hline & nonfin & nonfin & nonfin & nonfin & nonfin & fin & fin & fin & fin & fin \\
\hline ONSHORE & 0.00 & 0.00 & 0.00 & 0.00 & 0.54 & 0.23 & 0.09 & 0.19 & 0.29 & 0.59 \\
OFFEXP & 0.00 & 0.07 & 0.00 & 0.00 & 0.01 & 0.13 & 0.09 & 0.30 & 0.31 & 0.15 \\
STOCKCAP & 0.00 & 0.00 & 0.00 & 0.00 & 0.01 & 0.26 & 0.04 & 0.00 & 0.26 & 0.50 \\
BANKCR & 0.04 & 0.00 & 0.05 & 0.40 & 0.85 & 0.09 & 0.90 & 0.62 & 0.69 & 0.46 \\
TRVOL & 0.03 & 0.33 & 0.00 & 0.00 & 0.28 & 0.13 & 0.17 & 0.38 & 0.20 & 0.10 \\
SID & 0.00 & & 0.11 & 0.01 & 0.01 & 0.91 & & 0.04 & 0.53 & 0.48 \\
WITHTAX & & 0.06 & & & & & 0.03 & & & \\
CHINN-ITO & 0.00 & 0.06 & 0.00 & 0.00 & 0.06 & 0.02 & 0.84 & 0.08 & 0.16 & 0.56 \\
CHINN-ITO*SIZE & & & 0.73 & & & & & 0.00 & & \\
CHINN-ITO*ONSHORE & & & & 0.55 & & & & & 0.19 & \\
DERIV & & & & & 0.00 & & & & & 0.08 \\
\hline
\end{tabular}

Notes: The table reports p-values of a test statistic where the null hypothesis is the equality of the coefficients. 